\title{
A proteomic approach to evaluate the effects of endogenous expression of cryptogein gene in crypt- transgenic plants of Bacopa monnieri
}

\begin{abstract}
Cryptogein, a proteinaceous elicitor has been reported to affect growth and secondary metabolism in several plant species. We established two transgenic plant lines of Bacopa monnieri L., an indigenous medicinal species, following Agrobacterium tumefaciens mediated transformation. The transgenic plant lines obtained following transformation with strains LBA4404-nptII-crypt (plant line BmAt-ncrypt) and LBA4404-nptII (plant line BmAt-n), were maintained on selection media i.e. MS medium containing $100 \mathrm{mg} / 1$ Kanamycin. To evaluate the effects of endogenous expression of cryptogein gene in crypt-transgenic plants of $B$. monnieri, in the present study, a proteomic approach was employed. Using 2D-PAGE followed by MALDI TOF MS/MS, we found 54 spots with reproducible differences in abundance $(\geq+2$ or $\leq-0.5$-fold $)$ between the plant lines. Bioinformatics analyses helped their identification, functional annotation and categorization.

Significantly upregulated gene expression $(\mathrm{p} \leq 0.5)$ of most of the key enzymes of triterpenoid saponin biosynthetic pathway (mevalonate kinase, $m v k$; mevalonate diphosphate decarboxylase, $m d c$; squalene synthase, sqs; $\beta$-amyrin synthase, bas and UDP-glycosyl transferase 2, ugt 2) in crypt-transgenic plant lines (BmAt-ncrypt) of B. Monnieri was observed as compared to non-transformed (Bm-NT) and empty vector control (BmAt-n) plant lines. Cryptogein-induced ROS production, a typical stress response of plant cells towards cryptogein, was significantly increased $(p \leq 0.5)$ in specific activities and higher abundance of several anti-oxidant enzymes, such as SOD (3.0-5.0-fold), APX (2.3-3.0-fold) and CAT (2.6-fold) in BmAt-ncrypt. The upregulation of $\mathrm{CaM}$ (1.6-fold) and calcium-transporting ATPase-2 (2.0-fold) in BmAt-ncrypt indicate possible calcium-dependant cryptogein elicitation. A 3.0-fold increase in EIN3 levels with down-regulation of F-box protein, its regulator also indicate induction of JA-ET signalling pathway in crypt-transgenic plants. This study not only demonstrates involvement of multiple defence signalling pathways in crypttransgenic plants of $B$. monnieri but also shows first evidence of the involvement of JA-ET signalling in cryptogein-induced elicitation.
\end{abstract}

Keywords: bacopa monnieri, cryptogein, triterpenoid saponin biosynthetic pathway, leaf proteome, defence signalling pathways
Volume 4 Issue 3 - 2017

\author{
Pijush Paul,' Krishnadas Nandagopal,' Niraj \\ Agarwala, ${ }^{2}$ Sudripta Das, ${ }^{2,3}$ Sumita Jha, ${ }^{4}$ Binay \\ Chaubey ${ }^{4}$ \\ 'Department of Genetics, University of Calcutta, India \\ ${ }^{2}$ Department of Biotechnology, Tea Research Association, India \\ ${ }^{3}$ Indian Institute of Bioresources \& Sustainable Development, \\ India \\ ${ }^{4}$ Department of Botany, University of Calcutta, India
}

\begin{abstract}
Correspondence: Binay Chaubey, Centre of Advanced Study, Department of Botany, University of Calcutta, 35 Ballygunge Circular Road, Kolkata 700 019, West Bengal, India, Fax +91-33 246 | 4849, Tel +9l-33-246| 5445, Email bchaubey@hotmail.com
\end{abstract}

Received: October 24, 2017 | Published: December 12, 2017

\begin{abstract}
Abbreviations: HR, hypersensitive response; SAR, systemic acquired resistance; WIPK, wound-induced protein kinase; SIPK, salicylic acid-induced protein kinase; TCA, trichloroacetic acid; 2-ME, 2-mercaptoethanol; SDS, sodium dodecyl sulphate; PMSF, phenyl methyl sulfonyl fluoride; 2DE, 2D gel electrophoresis; DTT, dithiothreitol; aact, acetyl-coa c-acetyl transferase; qRT-PCR, quantitative real time PCR; $h m g r$, hydroxyl methyl glutaryl-coa reductase, $m v k$, mevalonate kinase, $m d c$, mevalonate diphosphate decarboxylase; fpps, farnesyl diphosphate synthase; sqs, squalene synthase; bas, $\beta$-amyrin synthase; ugt 1 , UDP-glycosyl transferase 1 ; fgt, flavonoid glucosyl transferase; $p r$ 1, pathogenesis-related 1; NBT, nitro-blue tetrazolium; ROS, reactive oxygen species; HSPs, heat shock proteins
\end{abstract}

\section{Introduction}

Cryptogein, a $10 \mathrm{kDa}$ sterol scavenging protein secreted by the oomycete Phytophthora cryptogea, ${ }^{1}$ belongs to 'elicitin' class of elicitors. ${ }^{2}$ Cryptogein has been used to study the underlying molecular mechanisms of disease resistance in tobacco. Application of purified cryptogein protein, even in nanomolar quantity causes hypersensitive response (HR)-like necrosis in tobacco plants ${ }^{3}$ and also induces systemic acquired resistance (SAR) to $P$. parasitica var nicotianae. ${ }^{4}$

There are several reports on transformation with cryptogein (crypt) gene aimed to achieve the resistance against plant pathogens. Over expression of $\beta$-cryptogein induces HR in tobacco and triggers resistance against $P$. parasitica var nicotianae. ${ }^{5,6}$ and other pathogens. Effective increase in biomass and/ or secondary metabolites accumulation in crypt-transgenic cultures in a number of plant species have also been observed, ${ }^{7-9}$ where the crypt gene was either under the constitutive promoter ${ }^{7}$ or under the inducible promoter. ${ }^{8}$

The biochemical mode of action of this elicitor has been extensively studied. The cryptogein initiates a signal transduction possibly by binding cryptogein to an $\mathrm{N}$-glycosylated plasma membrane receptor protein, ${ }^{10,11}$ followed by the activation of several protein kinases, such as the wound-induced protein kinase (WIPK), the salicylic acidinduced protein kinase (SIPK). ${ }^{12,13}$ Calcium influxes triggered by these kinases subsequently give rise to calcium-dependant transcriptional changes ${ }^{14}$ and activate a wide array of cellular responses, including 
an NADPH oxidase-dependent oxidative burst ${ }^{15,16}$ Upregulation of several chitinases, peroxidases, peptidyl-prolyl isomerases and proteinase inhibitors in intercellular fluid of cryptogein-treated tobacco leaves were observed using a proteomic approach. ${ }^{17}$

Bacopa monnieri (Scrophulariaceae), a herbaceous plant, has been used in Ayurvedic medicine in India for almost 3,000 years and is classified as medhya rasayana, a drug used to improve memory and intellect (medhya). Although different triterpenoid compounds are well distributed in plant kingdom, B. monnieri (popularly known as Brahmi) is the only herbal source of bacosides. ${ }^{18}$ We have been exploring various biotechnological approaches for improvement in production of active principles of B.monnieri. ${ }^{19,20}$

Cryptogein gene either alone or in association with Ri T-DNA genes have been implicated for increased levels of principal bioactive compounds viz., bacoside $\mathrm{A} 3$, bacopasaponins $(\mathrm{C}, \mathrm{D}$, and $\mathrm{F}$ ) and bacopasides (II and III) from B. Monnieri. ${ }^{19}$ The enhanced level of bacosides (1.66- to 2.05-fold as compared to non transformed plants) was stable for four years in plants maintained in vitro and the effects were sustained, even one year after transfer to greenhouse. ${ }^{20}$ However, the biochemical pathways leading to the biosynthesis of bacosides have not been fully elucidated so far.

In the present study, a proteomic approach using 2D-PAGE followed by MALDI TOF MS/MS analysis was employed to evaluate the effects of endogenous expression of cryptogein gene in crypttransgenic plants of $B$. monnieri.

In the present study leaf proteomes of $B$. monnieri plant line Bm-NT (non-transformed control) and three independent plant lines each of BmAt-n (empty vector controls) and Bm-At-ncrypt (crypt-transgenic plants) were analyzed and 54 spots with reproducible differential expression $(\geq+2$ or $\leq-0.5$-fold) were identified in crypt-transgenic plants of B. monnieri. Among these 54 spots, gene expression of most of the key enzymes of triterpenoid saponin biosynthetic pathway in crypt-transgenic plant lines were significantly upregulated $(p \leq 0.5)$ compared to non-transformed and empty vector control plant lines, as confirmed by qRT-PCR. In crypt-transgenic plants elevated ROS production in specific activities and higher abundance of several antioxidant enzymes, such as SOD (3.0-5.0-fold), APX (2.3-3.0-fold) and CAT (2.6-fold) was also noted along with up regulation of CaM (1.6-fold) and calcium-transporting ATPase-2 (2.0-fold), indicating possible calcium-dependant cryptogein elicitation.

In another interesting observation, 3.0-fold increase in EIN3 levels with down-regulation of F-box protein, its regulator, was noted which indicate induction of JA-ET signalling pathway in crypttransgenic plants. In present study we demonstrate the first evidence of involvement of JA-ET signalling in cryptogein-induced elicitation and also hypothesize involvement of multiple defence signalling pathways in crypt-transgenic plants of $B$. monnieri.

\section{Materials and methods}

\section{Plant materials}

For this study, transgenic $B$. monnieri plant lines were obtained via transformation with Agrobacterium tumefaciens strains LBA4404crypt (harboring pBin19++crypt) and LBA4404-npt II (harboring $\mathrm{pBin} 19++$, empty vector). The synthetic $\beta$-cryptogein (crypt) gene $\mathrm{g}^{21}$ was cloned under the $35 \mathrm{~S}$ CaMV promoter and NOS terminator in a pBin 19 vector. $^{5}$
Three independent crypt-transgenic plant lines, BmAt-ncrypt (harboring npt II and crypt genes) were selected to study the effect of endogenous expression of crypt gene in crypt-transgenic plant lines of B. monnieri. However, B. monnieri plant lines Bm-NT (nontransformed) and three independent plant lines of BmAt-n (empty vector control, harboring only npt II gene) were considered as controls. Representative specimens of the three plant lines have been shown in Supplementary Figure 1. The transgenic plant lines were raised as described previously. ${ }^{20}$ Southern hybridization analysis was performed to ensure the insertion of crypt gene into the genome of crypt-transgenic plant lines (Southern hybridisation details described in Supplementary Figure 2).
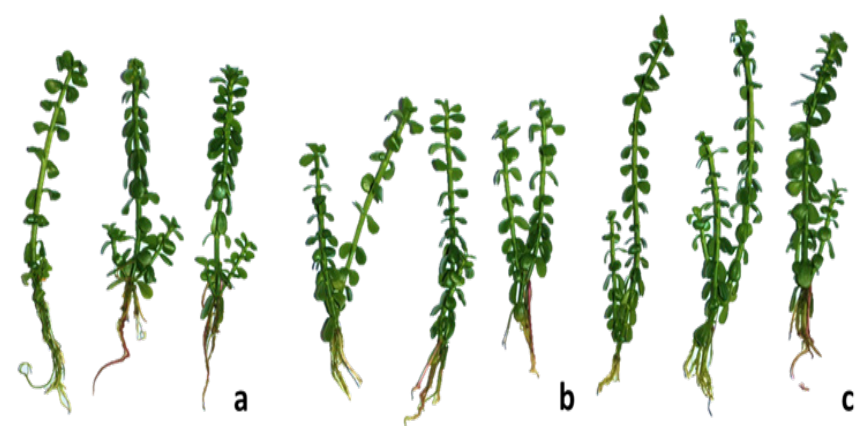

\section{Supplementary Figure I}

A. Three representative six week old non-transformed wild type plants (BmNT); representative six week old plants of three selected plant lines each of B. monnieri transgenic lines

\section{B. BmAt-n}

\section{BmAt-ncrypt. Bar $=1.8 \mathrm{~cm}$}

Leaf tissues were harvested from plantlets obtained after culturing $2 \mathrm{~cm}$ long shoot tip for 4 weeks on basal MS media with $3 \%$ sucrose and $0.8 \%$ agar to isolate total RNA or protein. Cultures were maintained at $24 \pm 1^{\circ} \mathrm{C}$ and $50-60 \%$ relative humidity under $16-/ 8$-h (light/dark) photoperiod.

\section{Protein extraction from B. monnieri leaves}

Total protein was extracted according to the method described by Wang et al. ${ }^{22}$ In brief, about $200 \mathrm{mg}$ leaf tissue was ground to fine powder in liquid nitrogen and immediately suspended in $800 \mu 1$ of ice cold $10 \%$ trichloroacetic acid (TCA) in acetone with $1 \%$ 2 -mercaptoethanol (2-ME). The mixture was vigorously vortexed and incubated at $-80 \mathrm{C}$ for $30 \mathrm{~min}$. After centrifugation (14000rpm, $4^{\circ} \mathrm{C}, 10 \mathrm{~min}$ ), the pellet was recovered and resuspended in ice cold $0.1 \mathrm{M}$ ammonium acetate in methanol. Subsequently, the mixture was vortexed and incubated at $-80^{\circ} \mathrm{C}$ for $30 \mathrm{~min}$. Pellet was recovered by centrifugation and washed once each with ice cold $0.1 \mathrm{M}$ ammonium acetate in methanol, ice cold methanol and $80 \%$ acetone. After $5 \mathrm{~min}$ of brief air drying equal volume of tris-saturated phenol ( $\mathrm{pH}$ 8.0) and SDS buffer [ $30 \%$ sucrose, $2 \%$ sodium dodecyl sulphate (SDS), $0.1 \mathrm{M}$ tris- $\mathrm{HCl}$ (pH 8.0), 5\% 2-ME, 1mM PMSF (Phenyl methyl sulfonyl fluride)] were added to the pellet, vortexed and incubated on ice for 10 min. After centrifugation $\left(14000 \mathrm{rpm}, 4^{\circ} \mathrm{C}, 10 \mathrm{~min}\right)$ the upper phenolic phase was taken out in fresh eppendorf tube, 5 volumes of ice cold $0.1 \mathrm{M}$ ammonium acetate in methanol was added to it and mixed well. The mixture was incubated at $-80^{\circ} \mathrm{C}$ for $1 \mathrm{~h}$. The recovered pellet was washed once each with ice cold methanol and $80 \%$ acetone. Pellet was air dried and stored at $-80^{\circ} \mathrm{C}$ for further $2 \mathrm{DE}$ analysis. 


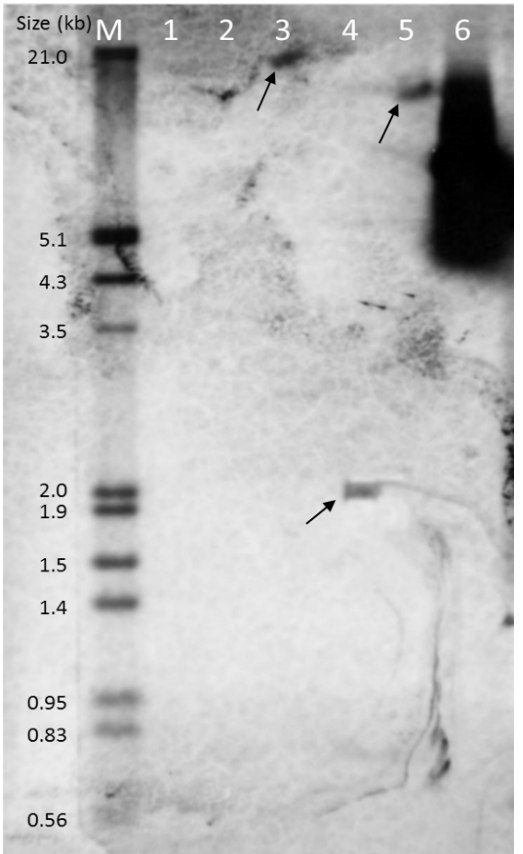

Supplementary Figure 2 Confirmation of integration of crypt in crypttransgenic plant lines (BmAt-ncrypt) of B. monnieri by Southern hybridisation.

Lane M DNA MolecularWeight Marker VI, DIG-labeled (Roche), lane I EcoRIdigested Bm-NT genomic DNA, lane 2 EcoRI-digested genomic DNA of BmAt-n plant lines, lane 3, 4 and 5 EcoRI-digested genomic DNA of three independent transgenic plant lines of BmAt-ncrypt (arrow indicates the cryptspecific band), lane 6 EcoRI-digested pBin l9++crypt plasmid DNA.

For Southern hybridisation, $20 \mu \mathrm{g}$ of EcoRI-digested genomic DNA from three selected crypt-transgenic plant lines of B. monnieri was electrophoresed on a $0.8 \%$ agarose gel and transferred to a nylon membrane (Hybond-N, Amersham) by capillary transfer. DNA was fixed to the membrane by UV cross-linking. The pre-hybridizations and hybridizations were performed in DIG Easy Hyb solution (Roche, Germany) at $42^{\circ} \mathrm{C}$. Double stranded probe for crypt gene was labelled with digoxigenin- I I-dUTP by random primed labelling using DIG DNA Labelling and Detection Kit (Roche, Germany).After hybridization, membranes were washed twice for 5 min with 2X SSC (3M $\mathrm{NaCl}, 0.3 \mathrm{M}$ sodium citrate, $\mathrm{pH} 7.0$ ), containing $0.1 \% \mathrm{SDS}$ at room temperature and then twice for $15 \mathrm{~min}$ with $0.5 \mathrm{XSC}$ containing $0.1 \% \mathrm{SDS}$ at $68^{\circ} \mathrm{C}$. The digoxigenin-labelled hybridization products were detected according to the manufacturer's instructions.

Southern hybridisation analysis confirmed integration of crypt into the genome of three selected BmAt-ncrypt plant lines. Detection of single cryptspecific band at three different positions in the blot suggests that the three crypt-transgenic plant lines were indeed arose from three independent transformation events and at the same time the crypt gene was integrated in single copy.

\section{D gel electrophoresis (2DE)}

For $2 \mathrm{DE}$ the protein pellet was dissolved in resolubilization buffer (8M urea, $2 \mathrm{M}$ thiourea, 4\% CHAPS) mixed with $2 \%$ IPG buffer ( $\mathrm{pH}$ 3-11) (GE Healthcare). Total protein content was determined following the method of Bradford $^{23}$ with bovine serum albumin (BSA) as standard. For first dimension of 2DE, IPG strips (Immobiline ${ }^{\mathrm{TM}}$ DryStrip, pH 3-11 NL, $11 \mathrm{~cm}$, GE Healthcare) were passively rehydrated overnight with $200 \mu$ l of $2 \mathrm{DE}$ sample buffer containing about $150 \mu \mathrm{g}$ protein. Isoelectric focusing was performed in a PROTEAN ${ }^{\circledR}$ IEF Cell (Bio-Rad) at $4000 \mathrm{~V}$ for $2 \mathrm{~h} 30 \mathrm{~min}$ with linear voltage amplification and finally to $8,000 \mathrm{Vh}$ with rapid amplification

The focused strips were equilibrated once each for $15 \mathrm{~min}$ in equilibration buffer I [50mM Tris- $\mathrm{HCl}, \mathrm{pH} 8.8,6 \mathrm{M}$ urea, 20\%[v/v] glycerol and $2 \%[\mathrm{w} / \mathrm{v}]$ (SDS) and 100mg dithiothreitol (DTT)] and equilibrium buffer II (with $250 \mathrm{mg}$ iodoacetamide). The equilibrated strips were then subjected to SDS-PAGE in a Criterion ${ }^{\mathrm{TM}}$ Cell (BIORAD, USA) at constant $180 \mathrm{~V}$ for $2 \mathrm{~h}$. After electrophoresis, gels were incubated for $30 \mathrm{~min}$ in the fixing solution (40\% methanol; $10 \%$ acetic acid). Thereafter, the gels were stained overnight in $0.12 \%(\mathrm{w} / \mathrm{v})$ Coomassie brilliant blue G-250 colloidal stain, destained and stored in $5 \%$ acetic acid for further analysis.

\section{Image and data analysis}

Coomassie stained 2D gels were visualized using Chemidoc ${ }^{\mathrm{TM}}$ XRS system (BIO-RAD, USA) and the gel images were analysed for spot detection, spot matching, background subtraction and spot intensity normalization using PD Quest Software, version 8.0 (BioRad). Automated matching was performed and spot alignment was improved by manual spot detection and matching. All protein spots detected in gel were matched with the corresponding spots of master gel (reference gel) and we normalized each spot density against the whole gel densities. In order to minimize variations in sample loading, gel staining, and destaining, data were normalized by expressing protein abundance as a percentage of the total spot volume in the gel (relative volume \%) to minimize gel-to-gel variation in spot intensity. The volume of the spot corresponded to the amount of protein expressed. The percentage volume of each spot was the average of the spot densities of nine different spots (three biological replicates of 3 plant lines BmAt-n=3x3=9; three biological replicates of 3 plant lines BmAt-ncrypt $=3 \times 3=9$. For control BmNT plant lines, which are all non transformed three biological replicates $n=3$ were used).

Statistical analysis was performed to determine the significant differences between the groups (Bm-NT, BmAt-n and BmAtncrypt). Only the spots present in all the three biological replicates for each plant line were considered for comparison. Spots showing reproducible fold change patterns (above 2.0-fold for up-regulation and below 0.5 -fold for down-regulation) and significant differences $(\mathrm{P}<0.05)$ were designated as differentially expressed proteins.

\section{Tryptic digestion and MALDI-TOF MS/MS analysis}

Selected protein spots were excised manually from the gels and washed three times with ultra-pure water. In-gel trypsin digestion of the spots were performed according to the protocol described by Shevchenko et al. ${ }^{24}$ Protein digests were finally dissolved in $0.1 \%$ TFA solution and digested samples were mixed $(1: 1, \mathrm{v} / \mathrm{v})$ with the matrix solution [ $\alpha$-cyano-4-hydroxycinnamic acid $(10 \mathrm{mg} / \mathrm{ml})$ in $50 \%(\mathrm{v} / \mathrm{v})$ ACN and $0 . \%(\mathrm{v} / \mathrm{v}) \mathrm{TFA}$, and $1 \mu \mathrm{l}$ of this mixture was spotted on the MALDI target plate (Bruker Daltonics, Germany). MALDI-TOF MS/MS analysis was performed in MALDI-TOF MS/MS analyser (Bruker Daltonics, Germany); MS/MS spectra were collected and subsequently analysed in Flex Analysis v3.4 software. The Protein search was carried out using MASCOT (Matrix Science, London, England) and identified by NCBI and UniProt nrprotein sequence database using a MOWSE algorithm as implemented in the MASCOT search engine version 3.5

For database searches following parameters were used: taxonomy: viridiplantae (green plants; 186963 sequences); cleavage specificity: trypsin with one missed cleavages allowed; mass tolerance of 
$100 \mathrm{ppm}$ for precursor ions and a tolerance of $0.7 \mathrm{Da}$ for the fragment ions; allowed modifications: carbamidomethyl (fixed), oxidation of methionine (variable); cleavage by trypsin: cuts C-terminal side of KR unless next residue is P. A Mascot score above 64 was considered as significant $(\mathrm{P}<0.05)$.

\section{Bioinformatics analysis}

To evaluate the functional categories and hierarchies of identified proteins, Blast2Go (v. 3.0) program and UniProt database were used. Subcellular localizations of proteins were predicted by WoLF PSORT online software. The theoretical peptide mass and $\mathrm{pI}$ of the polypeptides were evaluated at EXPASy.

\section{Relative gene expression (qRT-PCR) analysis of the en- zymes involved in MVA, triterpenoids, MEP and flava- noid pathways}

Total RNA, from the leaves of 4-weeks old plants, was extracted using RNAqueous Kit (Ambion, USA) and one $\mu \mathrm{g}$ total RNA was reverse transcribed using transcriptor first strand cDNA synthesis kit (Roche, Germany) following the manufacturer's protocol. Three independent RNA extractions from three biological replicates were used for the analysis, and three technical replicates were analyzed for each biological test sample $(n=3 \times 3=9)$.

To investigate the effect of crypt on expression of the genes encoding secondary metabolite pathway enzymes, quantitative real time PCR (qRT-PCR) of 13 genes [five genes involved in MVA pathway, viz., acetyl-CoA C-acetyl transferase (act), hydroxyl methyl glutaryl-CoA reductase $(h m g r)$, mevalonate kinase ( $m v k)$, mevalonate diphosphate decarboxylase $(m d c)$ and farnesyl diphosphate synthase (fpps); four genes involved in triterpenoid saponin biosynthesis, viz., squalene synthase (sqs), $\beta$-amyrin synthase (bas), UDP-glycosyl transferase 1 (ugt 1), UDP-glycosyl transferase 2 (ugt 2); one gene each of MEP (1-deoxy-D-xylulose-5-phosphate synthase, $d x s$ ), shikimic acid pathway (3-deoxy-D-arabino-heptulosonate-7-phosphate synthase, $d a h s$ ) and flavonoid biosynthesis (flavonoid glucosyl transferase, $f g t$ ); pathogenesis-related 1 ( $p r$ l) was included as defence marker] was performed for the plant lines Bm-NT, BmAt-n and BmAt-ncrypt. For internal standard three reference genes were selected, viz, 18S rRNA, 26S rRNA and $\beta$-actin. Primer details of the genes are tabulated in Supplementary Table 1 .

LightCycler 480 SYBR green I Master kit (Roche Diagnostics, Germany) was used to carry out the expression assays using LightCycler 480 II (Roche, Germany). The first strand cDNA was used as template. All the reactions were carried out in $10 \mu 1$ reaction volume according to manufacturer's protocol. The following amplification programme was used: pre incubation at $95^{\circ} \mathrm{C}$ for $5 \mathrm{~min}$, followed by 45 cycles of amplification, each cycle comprised of 10 s denaturation at $95^{\circ} \mathrm{C}, 15 \mathrm{~s}$ annealing at respective temperatures as optimized for each set of primers and $30 \mathrm{~s}$ extension at $72^{\circ} \mathrm{C}$. This was followed by one cycle of melting curve analysis to check specificity of amplified product at $95^{\circ} \mathrm{C}$ for $5 \mathrm{~s}, 65^{\circ} \mathrm{C}$ for $1 \mathrm{~min}$ and $97^{\circ} \mathrm{C}$ for continuous acquisition. This was followed by one cycle of final cooling at $4^{\circ} \mathrm{C}$.

The geNorm software was used to find out the most stable genes among the set of reference genes. In this study, the raw $\mathrm{Cp}$ values of all the reference genes are transformed into relative quantities using $\Delta \Delta \mathrm{Ct}$ method. ${ }^{25}$ For relative quantification assays, the expression of the target gene is expressed as ratio of target-to-reference gene in the same sample. Melting curves for the genes are shown in Supplementary Figure 3.

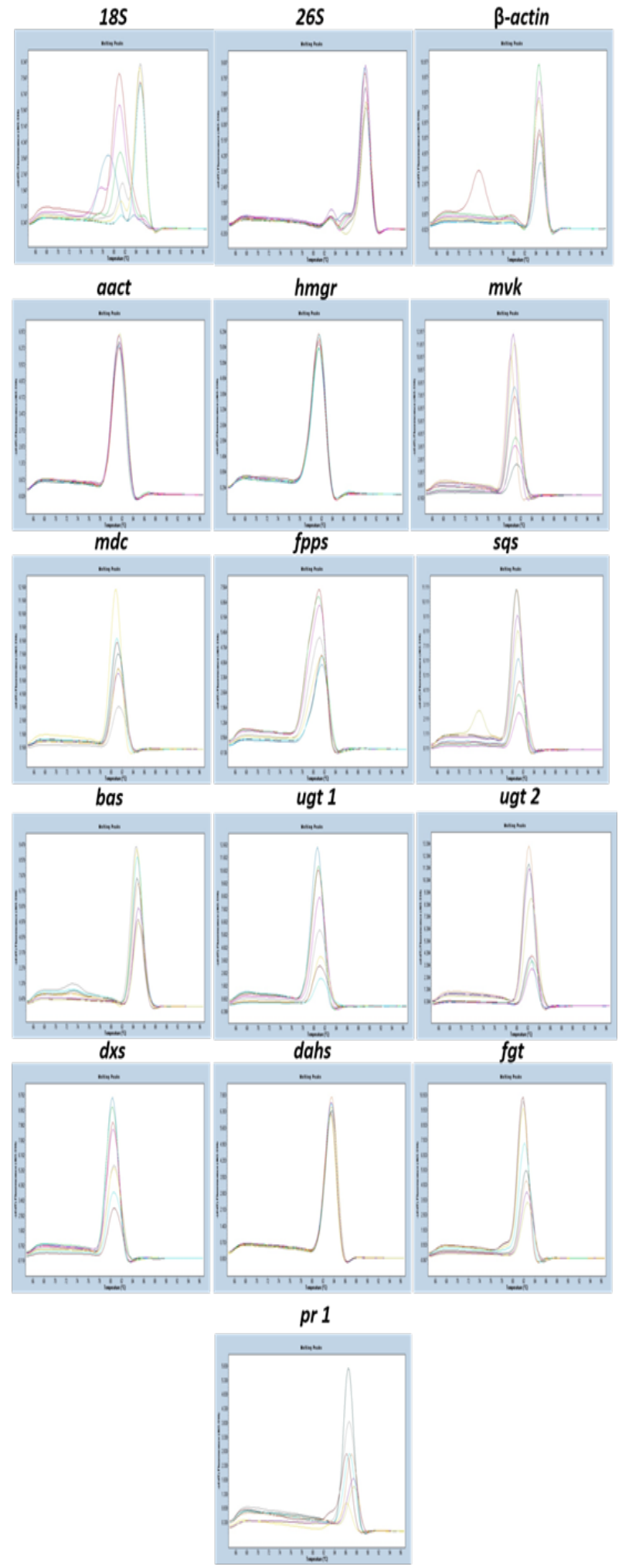

Supplementary Figure 3 Melting curve of three reference genes and the 13 genes related to secondary metabolism and defence responses analysed in this study. 


\section{Anti-oxidant enzyme assay}

Leaf tissues $(0.5 \mathrm{~g})$ were ground in a pre-chilled mortar and pestle in liquid nitrogen with $2 \mathrm{ml}$ extraction buffer $(50 \mathrm{mM}$ potassium phosphate buffer $\mathrm{pH} 7.5,1 \mathrm{mM}$ EDTA, 1mM PMSF). For analysis of APX, the extraction buffer also contained $5 \mathrm{mM}$ ascorbate. The homogenate was centrifuged at $8000 \mathrm{rpm}$ for $15 \mathrm{~min}$ at $4^{\circ} \mathrm{C}$ and the supernatant collected. Total protein content was determined following the method of Bradford ${ }^{23}$ with BSA as standard.

Catalase (CAT, EC 1.11.1.6) activity was estimated according to Bergmeyer method, ${ }^{26}$ which measures the initial rate of disappearance of $\mathrm{H}_{2} \mathrm{O}_{2}$ at $240 \mathrm{~nm}$. The decrease in the absorption was followed for 3 min and $1 \mathrm{mmol} \mathrm{H}_{2} \mathrm{O}_{2} \mathrm{ml}^{-1} \mathrm{~min}^{-1}$ was defined as 1 unit of CAT.

Ascorbate peroxidase (APX, EC 1.11.1.11) activity was measured as described by Nakano et al. ${ }^{27}$ The assay depends on the decrease in absorbance at $290 \mathrm{~nm}$ as ascorbate was oxidized. The concentration of oxidized ascorbate was calculated by using extinction coefficient of $2.8 \mathrm{mM}^{-1} \mathrm{~cm}^{-1}$. One unit of APX was defined as $1 \mathrm{mmol} \mathrm{ml}^{-1}$ ascorbate oxidized $\mathrm{min}^{-1}$.

Guaiacol peroxidase (GPX, EC 1.11.1.7) activity was determined by measuring the increase of absorbance at $436 \mathrm{~nm}$ for $5 \mathrm{~min}$ relative to guaiacol oxidation to tetraguaiacol $\left(\varepsilon=25.5 \times 10^{3} \mathrm{~L} \mathrm{~mol}^{-1} \mathrm{~cm}^{-1}\right) .{ }^{28}$ One unit of GPX was defined as $1 \mu \mathrm{M}$ guaiacol oxidised $\mathrm{min}^{-1}$.

Superoxide dismutase (SOD, EC 1.15.1.1) activity was assayed by measuring the inhibition of photo reduction of nitro-blue tetrazolium (NBT). ${ }^{29}$ One unit of enzyme activity is defined as the amount of enzyme required to inhibit the NBT reduction by $50 \%$.

\section{Statistical analysis}

Data from three independent transgenic lines for each of the transformed B. monnieri plant lines (BmAt-n and BmAt-ncrypt) were used for statistical analysis. All the experiments were randomized and repeated at least three times. Data were examined by a oneway analysis of variance (ANOVA) to detect significant differences $(p \leq 0.05)$ in the mean. A post hoc mean separation was performed by the Tukey's multiple comparison tests at the $5 \%$ probability level using SPSS software (version 20.0). Variability in the data was expressed as the mean \pm standard deviation (SD), if not mentioned otherwise.

\section{Results}

\section{Comparison of leaf proteomes of B. monnieri plant li- nes}

The leaf proteome profiles of B. Monnieri plant line Bm-NT and three independent transgenic lines of BmAt-n and Bm-At-ncrypt were analyzed by 2D-PAGE followed by MALDI TOF MS/MS and spots with reproducible differences in abundance $(\geq+2$ or $\leq-0.5$-fold $)$ between the plants lines were targeted for further analysis (Figure 1). Following this criterion 54 spots (Table 1) were detected which were functionally annotated and grouped into nine different functional categories using different protein databases (Supplementary Figure 4). Between BmAt-ncrypt and Bm-NT plant lines $85 \%$ and $12 \%$ of the differentially abundant proteins were found to be up-regulated and downregulated respectively in BmAt-ncrypt plant lines. However, $90 \%$ of the differentially abundant proteins were up-regulated in BmAt-ncrypt in comparison with BmAt-n plant lines, whereas, $7 \%$ of differentially abundant proteins were downregulated. When the leaf proteome of BmAt-n plant lines were compared with that of Bm-NT, $15 \%$ and $54 \%$ of the differentially abundant proteins were found to be up-regulated and downregulated respectively in BmAt-n plant lines (Supplementary Table 2).

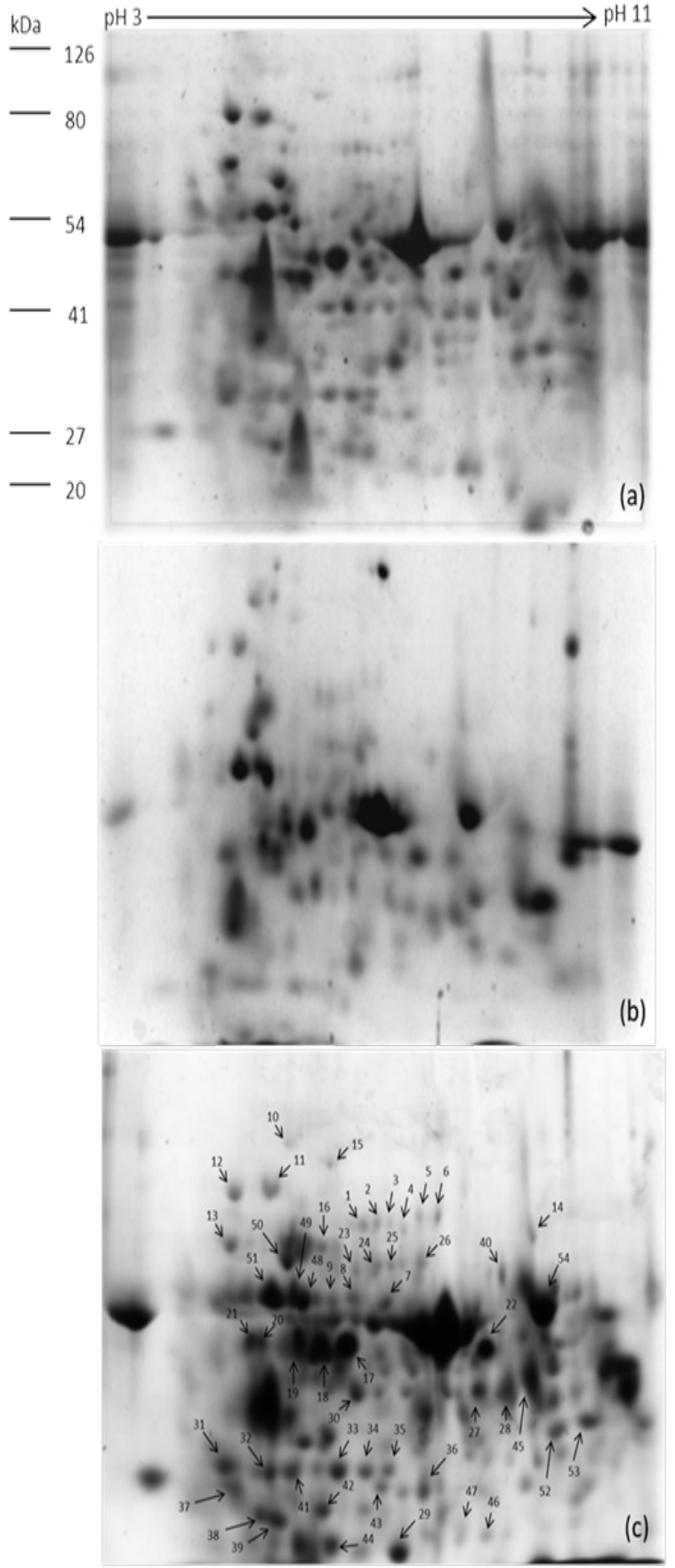

Figure I Representative 2DE gels of
A. Bm-NT
B. BmAt-n
C. BmAt-ncrypt

Arrow indicates the differentially abundant proteins which were subjected to MALDI-TOF MS/MS analysis. 
Table I A summary of differentially abundant proteins in the leaf proteome of Bm-NT, BmAt-n and BmAt-ncrypt plant lines identified using MALDI-TOF MS/ MS analysis

\begin{tabular}{|c|c|c|c|c|c|c|c|c|c|}
\hline $\begin{array}{l}\text { Spot } \\
\text { No. }\end{array}$ & $\begin{array}{l}\text { Name of the } \\
\text { predicted } \\
\text { protein }\end{array}$ & Organism & Localization & $\begin{array}{l}\text { Accession } \\
\text { number } *\end{array}$ & $\begin{array}{l}\text { Mascot } \\
\text { score }\end{array}$ & $\begin{array}{l}\text { Theo. } \\
\text { Mr./pl \# }\end{array}$ & $\begin{array}{l}\text { Expt. } \\
\text { Mr./pl† }\end{array}$ & $\begin{array}{l}\text { Matched } \\
\text { peptides }\end{array}$ & $\begin{array}{l}\text { Sequence } \\
\text { coverage } \\
(\%)\end{array}$ \\
\hline 5 & $\begin{array}{l}\text { Succinate } \\
\text { dehydrogenase } \\
\text { [ubiquinone] } \\
\text { flavoprotein } \\
\text { subunit }\end{array}$ & $\begin{array}{l}\text { Oryzasativa subsp. } \\
\text { japonica }\end{array}$ & Mitochondria & $\begin{array}{l}\text { SDHA } \\
\text { ORYS] }\end{array}$ & 75 & $68.8 / 6.61$ & $71.6 / 5.83$ & 6 & 47 \\
\hline 10 & $\begin{array}{l}\text { Pyruvate } \\
\text { phosphate } \\
\text { dikinase }\end{array}$ & Flaveriabrownii & Chloroplast & gi|3024423 & 133 & $104.2 / 5.9 \mid$ & $92.4 / 5.48$ & 8 & 40 \\
\hline 15 & $\begin{array}{l}\text { Vacuolar } \mathrm{H+-} \\
\text { ATPase AI } \\
\text { subunit isoform }\end{array}$ & Solanum lycopersicum & Vacuole & gi|92 I 274020 & 176 & $68.5 / 5.2$ & $90.1 / 5.65$ & 9 & 34 \\
\hline 28 & $\begin{array}{l}\text { Glyceraldehyde- } \\
\text { 3-phosphate } \\
\text { dehydrogenase }\end{array}$ & Petunia $x$ hybrida & Cytoplasm & $\begin{array}{l}\text { G3PC } \\
\text { PETHY }\end{array}$ & 127 & $36.5 / 6.68$ & $42.8 / 7.04$ & 12 & 47 \\
\hline 39 & $\begin{array}{l}\text { PREDICTED: } \\
\text { triosephosphate } \\
\text { isomerase, } \\
\text { chloroplastic- } \\
\text { like }\end{array}$ & Cucumissativus & Chloroplast & gi|449458564 & 221 & $32.7 / 7.01$ & $25.8 / 5.45$ & 8 & 18 \\
\hline 43 & $\begin{array}{l}\text { PREDICTED: } \\
\text { triosephosphate } \\
\text { isomerase, } \\
\text { cytosolic-like }\end{array}$ & $\begin{array}{l}\text { Fragariavesca subsp. } \\
\text { vesca }\end{array}$ & Cytoplasm & gi|470|43704 & 173 & $27.1 / 6.34$ & $27.8 / 6.14$ & 8 & 44 \\
\hline 48 & $\begin{array}{l}\text { ATP synthase } \\
\text { CFI alpha } \\
\text { subunit }\end{array}$ & Oryzasativa Japonica & Chloroplast & gi|257042663 & 179 & $36.0 / 5.22$ & $55.8 / 5.48$ & 8 & 22 \\
\hline 49 & $\begin{array}{l}\text { PREDICTED: } \\
\text { ATP synthase } \\
\text { subunit beta, } \\
\text { mitochondrial- } \\
\text { like }\end{array}$ & Vitisvinifera & Mitochondria & gi|225456079 & 496 & $59.1 / 5.9$ & $61.1 / 5.41$ & 10 & 27 \\
\hline 51 & $\begin{array}{l}\text { ATP synthase } \\
\text { subunit beta }\end{array}$ & Ticodendronincognitum & Chloroplast & gi|377294I4 & 707 & $50.8 / 5.25$ & $58.3 / 5.28$ & 13 & 12 \\
\hline
\end{tabular}

A. Proteins related to metabolism and energy

\begin{tabular}{|c|c|c|c|c|c|c|c|c|c|}
\hline $\begin{array}{l}\text { Spot } \\
\text { No. }\end{array}$ & $\begin{array}{l}\text { Name of the } \\
\text { predicted protein }\end{array}$ & Organism & Localization & $\begin{array}{l}\text { Accession } \\
\text { number }\end{array}$ & $\begin{array}{l}\text { Mascot } \\
\text { score }\end{array}$ & $\begin{array}{l}\text { Theo. } \\
\text { Mr./pl \# }\end{array}$ & $\begin{array}{l}\text { Expt. } \\
\text { Mr./pl }\end{array}$ & $\begin{array}{l}\text { Matched } \\
\text { peptides }\end{array}$ & $\begin{array}{l}\text { Sequence } \\
\text { coverage } \\
(\%)\end{array}$ \\
\hline 6 & $\begin{array}{l}\text { Photosystem I } \\
\text { assembly protein Ycf4 }\end{array}$ & Drimysgranadensis & Chloroplast & $\begin{array}{l}\text { YCF4 } \\
\text { DRIGR }\end{array}$ & 153 & $21.4 / 9.54$ & $71.9 / 6.07$ & 5 & 8 \\
\hline 17 & $\begin{array}{l}\text { Ribulose } \\
\text { bisphosphate } \\
\text { carboxylase/ } \\
\text { oxygenase activase }\end{array}$ & Phaseolus vulgaris & Chloroplast & $\begin{array}{l}\text { RCA } \\
\text { PHAVU }\end{array}$ & 159 & $48.2 / 8.19$ & $52.8 / 5.83$ & 9 & 35 \\
\hline 23 & $\begin{array}{l}\text { RuBisCO large } \\
\text { subunit-binding } \\
\text { protein subunit alpha }\end{array}$ & Brassica napus & Chloroplast & gi|464727 & 235 & $61.6 / 5.14$ & 66.8/5.7I & 10 & 18 \\
\hline
\end{tabular}


Table Continued.

\begin{tabular}{|c|c|c|c|c|c|c|c|c|c|}
\hline $\begin{array}{l}\text { Spot } \\
\text { No. }\end{array}$ & $\begin{array}{l}\text { Name of the } \\
\text { predicted protein }\end{array}$ & Organism & Localization & $\begin{array}{l}\text { Accession } \\
\text { number* }\end{array}$ & $\begin{array}{l}\text { Mascot } \\
\text { score }\end{array}$ & $\begin{array}{l}\text { Theo. } \\
\text { Mr./pl \# }\end{array}$ & $\begin{array}{l}\text { Expt. } \\
\text { Mr./pl } \dagger\end{array}$ & $\begin{array}{l}\text { Matched } \\
\text { peptides }\end{array}$ & $\begin{array}{l}\text { Sequence } \\
\text { coverage } \\
\text { (\%) }\end{array}$ \\
\hline 38 & $\begin{array}{l}\text { Harpin binding } \\
\text { protein I }\end{array}$ & Zea mays & Chloroplast & gi|29333430I & 241 & $29.3 / 9.57$ & $23.4 / 5.43$ & 7 & 4 \\
\hline 52 & $\begin{array}{l}\text { Ribulosebisphosphate } \\
\text { carboxylase small } \\
\text { chain }\end{array}$ & Betula pendula & Chloroplast & RBS_BETPN & 126 & $20.4 / 8.88$ & $36.5 / 7.84$ & 7 & 75 \\
\hline 53 & $\begin{array}{l}\text { Ribulosebisphosphate } \\
\text { carboxylase small } \\
\text { chain } 6\end{array}$ & Flaveriapringlei & Chloroplast & RBS6_FLAPR & 176 & 19.7/9.07 & $39.3 / 9.01$ & 4 & 32 \\
\hline
\end{tabular}

B. Proteins related to photosynthesis and chloroplast organization

\begin{tabular}{|c|c|c|c|c|c|c|c|c|c|}
\hline $\begin{array}{l}\text { Spot } \\
\text { No. }\end{array}$ & $\begin{array}{l}\text { Name of the } \\
\text { predicted protein }\end{array}$ & Organism & Localization & $\begin{array}{l}\text { Accession } \\
\text { number } *\end{array}$ & $\begin{array}{l}\text { Mascot } \\
\text { score }\end{array}$ & $\begin{array}{l}\text { Theo. } \\
\text { Mr./pl \# }\end{array}$ & $\begin{array}{l}\text { Expt. } \\
\text { Mr./pl } \dagger\end{array}$ & $\begin{array}{l}\text { Matched } \\
\text { peptides }\end{array}$ & $\begin{array}{l}\text { Sequence } \\
\text { coverage } \\
\text { (\%) }\end{array}$ \\
\hline I & $\begin{array}{l}50 \mathrm{~S} \text { ribosomal } \\
\text { protein } \mathrm{LI}\end{array}$ & $\begin{array}{l}\text { Arabidopsis } \\
\text { thaliana }\end{array}$ & Chloroplast & RKI_ARATH & 147 & $37.6 / 9.3$ & $70.6 / 5.91$ & 7 & 35 \\
\hline 9 & $\begin{array}{l}\text { Clathrin heavy chain, } \\
\text { partial }\end{array}$ & Oryzaminuta & Cytoplasm & gi|28855 I 237 & 148 & $7.5 / 5.01$ & $61.3 / 5.43$ & 6 & 3 \\
\hline 24 & $\begin{array}{l}\text { VAMP-like protein } \\
\text { YKT6I }\end{array}$ & $\begin{array}{l}\text { Arabidopsis } \\
\text { thaliana }\end{array}$ & Cytoplasm & $\begin{array}{l}\text { YKT6I- } \\
\text { ARATH }\end{array}$ & 92 & $22.5 / 6.96$ & $66.9 / 6.11$ & 11 & 27 \\
\hline 25 & $\begin{array}{l}\text { Brefeldin A-inhibited } \\
\text { guanine nucleotide- } \\
\text { exchange protein } 3\end{array}$ & $\begin{array}{l}\text { Arabidopsis } \\
\text { thaliana }\end{array}$ & Cytoplasm & $\begin{array}{l}\text { BIG3 } \\
\text { ARATH }\end{array}$ & 77 & $19.5 / 5.43$ & $67.7 / 6.16$ & 4 & 7 \\
\hline 46 & Cyclophylin I & Vignaradiata & Cytoplasm & gi| $|8| 46786$ & 192 & $18.2 / 8.69$ & $20.0 / 7.78$ & 8 & 18 \\
\hline 50 & $\begin{array}{l}\text { TCP-I/cpn60 } \\
\text { chaperonin family } \\
\text { protein }\end{array}$ & $\begin{array}{l}\text { Arabidopsis } \\
\text { thaliana }\end{array}$ & Chloroplast & gi||1523| 255 & 274 & $63.3 / 5.6$ & $70.4 / 5.55$ & 9 & 15 \\
\hline 54 & $\begin{array}{l}\text { Elongation factor } \\
\text { I-alpha }\end{array}$ & Glycine max & Cytoplasm & $\begin{array}{l}\text { EFIA } \\
\text { SOYBN }\end{array}$ & 205 & $49.4 / 9.14$ & $54.5 / 8.97$ & 9 & 26 \\
\hline
\end{tabular}

C. Proteins related to protein synthesis, folding and transport

\begin{tabular}{|c|c|c|c|c|c|c|c|c|c|}
\hline $\begin{array}{l}\text { Spot } \\
\text { No. }\end{array}$ & $\begin{array}{l}\text { Name of the } \\
\text { predicted } \\
\text { protein }\end{array}$ & Organism & Localization & $\begin{array}{l}\text { Accession } \\
\text { number * }\end{array}$ & $\begin{array}{l}\text { Mascot } \\
\text { score }\end{array}$ & $\begin{array}{l}\text { Theo. } \\
\text { Mr./pl \# }\end{array}$ & $\begin{array}{l}\text { Expt. } \\
\text { Mr./pl } \dagger\end{array}$ & $\begin{array}{l}\text { Matched } \\
\text { peptides }\end{array}$ & $\begin{array}{l}\text { Sequence } \\
\text { coverage } \\
(\%)\end{array}$ \\
\hline 4 & $\begin{array}{l}\text { Glutathione } \\
\text { gamma- } \\
\text { glutamylcysteinyl } \\
\text { transferase } 2\end{array}$ & Arabidopsis thaliana & Nucleus & $\begin{array}{l}\text { PCS2 } \\
\text { ARATH }\end{array}$ & 154 & $51.6 / 6.58$ & $67.8 / 5.98$ & 3 & 26 \\
\hline II & $\begin{array}{l}\text { Heat shock } \\
\text { 70kDa protein } \\
\text { I/8 }\end{array}$ & Arabidopsis thaliana & Chloroplast & gi| 1865 I 9455 & 228 & $57.2 / 5.01$ & $75.2 / 5.32$ & 9 & 72 \\
\hline 12 & $\begin{array}{l}\text { Stromal } 70 \mathrm{kDa} \\
\text { heat shock- } \\
\text { related protein }\end{array}$ & Arabidopsis thaliana & Chloroplast & gi|| 7083 I I & 244 & $64.9 / 4.87$ & $75.6 / 5.07$ & 6 & 17 \\
\hline 13 & $\begin{array}{l}\text { BAG family } \\
\text { molecular } \\
\text { chaperone } \\
\text { regulator I }\end{array}$ & Arabidopsis thaliana & Peroxisome & $\begin{array}{l}\text { BAGI- } \\
\text { ARATH }\end{array}$ & 68 & $38.2 / 9.24$ & 73.5/5.1I & 8 & 6 \\
\hline 27 & Catalase & Brassica juncea & Peroxisome & gi|4336754 & 181 & $56.8 / 6.63$ & $42.1 / 6.59$ & II & 66 \\
\hline 29 & $\begin{array}{l}\text { Iron superoxide } \\
\text { dismutase, } \\
\text { partial }\end{array}$ & Solanum tuberosum & Mitochondria & gi|2754337। & 113 & $21.3 / 5.87$ & $19.8 / 5.86$ & 5 & 21 \\
\hline 33 & $\begin{array}{l}\text { Ascorbate } \\
\text { peroxidase }\end{array}$ & Rehmanniaglutinosa & Mitochondria & gi|42558486 & 299 & $27.5 / 5.52$ & $29.9 / 5.61$ & 8 & 17 \\
\hline
\end{tabular}


Table Continued.

\begin{tabular}{|c|c|c|c|c|c|c|c|c|c|}
\hline $\begin{array}{l}\text { Spot } \\
\text { No. }\end{array}$ & $\begin{array}{l}\text { Name of the } \\
\text { predicted } \\
\text { protein }\end{array}$ & Organism & Localization & $\begin{array}{l}\text { Accession } \\
\text { number }\end{array}$ & $\begin{array}{l}\text { Mascot } \\
\text { score }\end{array}$ & $\begin{array}{l}\text { Theo. } \\
\text { Mr./pl \# }\end{array}$ & $\begin{array}{l}\text { Expt. } \\
\text { Mr./pl† }\end{array}$ & $\begin{array}{l}\text { Matched } \\
\text { peptides }\end{array}$ & $\begin{array}{l}\text { Sequence } \\
\text { coverage } \\
(\%)\end{array}$ \\
\hline 34 & $\begin{array}{l}\text { Cytosolic } \\
\text { ascorbate } \\
\text { peroxidase, } \\
\text { partial }\end{array}$ & Cucumissativus & Cytoplasm & gi| I I 7662088 & 160 & $16.9 / 6.48$ & $30.6 / 5.75$ & 3 & 6 \\
\hline 44 & $\begin{array}{l}\text { Superoxide } \\
\text { dismutase [Fe] }\end{array}$ & Nicotianaplumbaginifolia & Chloroplast & gi| | 34642 & 103 & $23.0 / 5.53$ & $20.4 / 5.54$ & 5 & 43 \\
\hline
\end{tabular}

D. Proteins related to stress and defence

\begin{tabular}{|c|c|c|c|c|c|c|c|c|c|}
\hline $\begin{array}{l}\text { Spot } \\
\text { No. }\end{array}$ & $\begin{array}{l}\text { Name of the } \\
\text { predicted } \\
\text { protein }\end{array}$ & Organism & Localization & $\begin{array}{l}\text { Accession } \\
\text { number } *\end{array}$ & $\begin{array}{l}\text { Mascot } \\
\text { score }\end{array}$ & $\begin{array}{l}\text { Theo. } \\
\text { Mr./pl \# }\end{array}$ & $\begin{array}{l}\text { Expt. } \\
\text { Mr./pl† }\end{array}$ & $\begin{array}{l}\text { Matched } \\
\text { peptides }\end{array}$ & $\begin{array}{l}\text { Sequence } \\
\text { coverage } \\
(\%)\end{array}$ \\
\hline 7 & $\begin{array}{l}\text { Ethylene } \\
\text { insensitive } 3\end{array}$ & $\begin{array}{l}\text { Arabidopsis } \\
\text { thaliana }\end{array}$ & Nucleus & $\begin{array}{l}\text { EIN3 } \\
\text { ARATH }\end{array}$ & 139 & $71.4 / 5.62$ & $60.2 / 5.76$ & 6 & 16 \\
\hline 8 & $\begin{array}{l}\text { Calcium- } \\
\text { transporting } \\
\text { ATPase } 2\end{array}$ & $\begin{array}{l}\text { Oryzasativa } \\
\text { Japonica }\end{array}$ & Chloroplast & $\begin{array}{l}\text { ACA2 } \\
\text { ORYS] }\end{array}$ & 150 & $111.7 / 5.6$ & $62.1 / 5.57$ & 3 & 10 \\
\hline 31 & Calmodulin & $\begin{array}{l}\text { Solanum } \\
\text { lycopersicum }\end{array}$ & Nucleus & $\begin{array}{l}\text { CALM_- } \\
\text { SOLLC }\end{array}$ & 114 & $16.9 / 4.15$ & $26.3 / 4.32$ & 5 & 29 \\
\hline 42 & $\begin{array}{l}\text { MYB } \\
\text { transcription } \\
\text { factor R2R3 } \\
\text { domain }\end{array}$ & $\begin{array}{l}\text { Camellia } \\
\text { sinensis }\end{array}$ & Nucleus & gi| | 9840032 I & 95 & $31.9 / 8.54$ & $24.7 / 5.54$ & 4 & 5 \\
\hline
\end{tabular}

E. Proteins related to transcription factor and signal transduction

\begin{tabular}{|c|c|c|c|c|c|c|c|c|c|}
\hline $\begin{array}{l}\text { Spot } \\
\text { No. }\end{array}$ & $\begin{array}{l}\text { Name of the } \\
\text { predicted protein }\end{array}$ & Organism & Localization & $\begin{array}{l}\text { Accession } \\
\text { number } *\end{array}$ & $\begin{array}{l}\text { Mascot } \\
\text { Score }\end{array}$ & $\begin{array}{l}\text { Theo. } \\
\text { Mr./pl \# }\end{array}$ & $\begin{array}{l}\text { Expt. } \\
\text { Mr./pl† }\end{array}$ & $\begin{array}{l}\text { Matched } \\
\text { peptides }\end{array}$ & $\begin{array}{l}\text { Sequence } \\
\text { coverage } \\
(\%)\end{array}$ \\
\hline 19 & $\begin{array}{l}\text { PREDICTED: actin- } \\
\text { 97-like }\end{array}$ & $\begin{array}{l}\text { Fragariavesca } \\
\text { subsp.Vesca }\end{array}$ & Cytoskeleton & gi|470|437I8 & 221 & $4 I .7 / 5.31$ & $52.6 / 5.35$ & 12 & 30 \\
\hline 41 & Formin-like protein I & Triticumurartu & Cytoplasm & gi|4744|4632 & 97 & $57.4 / 6.38$ & $28.4 / 5.33$ & 3 & 4 \\
\hline 47 & $\begin{array}{l}\text { Glycine-rich cell wall } \\
\text { structural protein I.8 } \\
\text { precursor, putative }\end{array}$ & Ricinuscommunis & $\begin{array}{l}\text { Extracellular } \\
\text { matrix }\end{array}$ & gi|255575788 & 177 & $28.7 / 5.83$ & $25.7 / 6.13$ & 5 & 7 \\
\hline
\end{tabular}

F. Structural proteins

\begin{tabular}{|c|c|c|c|c|c|c|c|c|c|}
\hline $\begin{array}{l}\text { Spot } \\
\text { No. }\end{array}$ & $\begin{array}{l}\text { Name of the } \\
\text { predicted protein }\end{array}$ & Organism & Localization & $\begin{array}{l}\text { Accession } \\
\text { number } *\end{array}$ & $\begin{array}{l}\text { Mascot } \\
\text { score }\end{array}$ & $\begin{array}{l}\text { Theo. } \\
\text { Mr./pl \# }\end{array}$ & $\begin{array}{l}\text { Expt. } \\
\text { Mr./pl† }\end{array}$ & $\begin{array}{l}\text { Matched } \\
\text { peptides }\end{array}$ & $\begin{array}{l}\text { Sequence } \\
\text { coverage } \\
(\%)\end{array}$ \\
\hline
\end{tabular}

G. Proteins related to secondary metabolism 
Table Continued..

\begin{tabular}{|c|c|c|c|c|c|c|c|c|c|}
\hline $\begin{array}{l}\text { Spot } \\
\text { No. }\end{array}$ & $\begin{array}{l}\text { Name of the } \\
\text { predicted } \\
\text { protein }\end{array}$ & Organism & Localization & $\begin{array}{l}\text { Accession } \\
\text { number }\end{array}$ & $\begin{array}{l}\text { Mascot } \\
\text { score }\end{array}$ & $\begin{array}{l}\text { Theo. } \\
\text { Mr./pl \# }\end{array}$ & $\begin{array}{l}\text { Expt. } \\
\text { Mr./pl† }\end{array}$ & $\begin{array}{l}\text { Matched } \\
\text { peptides }\end{array}$ & $\begin{array}{l}\text { Sequence } \\
\text { coverage } \\
(\%)\end{array}$ \\
\hline 14 & $\begin{array}{l}\text { Phosphate carrier } \\
\text { protein } 3\end{array}$ & Arabidopsis thaliana & Mitochondria & $\begin{array}{l}\text { MPCP3 } \\
\text { ARATH }\end{array}$ & 71 & $40.1 / 9.29$ & $75.4 / 8.41$ & 4 & 5 \\
\hline 21 & $\begin{array}{l}\text { Retrotransposon } \\
\text { protein, putative, } \\
\text { unclassified }\end{array}$ & $\begin{array}{l}\text { Oryza sativa } \\
\text { Japonica }\end{array}$ & Nucleus & gi|| 08708750 & 113 & $215.7 / 6.07$ & $54.3 / 5.21$ & 5 & 6 \\
\hline
\end{tabular}

H. Miscellaneous.

* UniProt or GenBank ID

\# Theo. Mr./pl:Theoretical molecular weight/isoelectric point

† Expt. Mr./pl: Experimental molecular weight/isoelectric point.

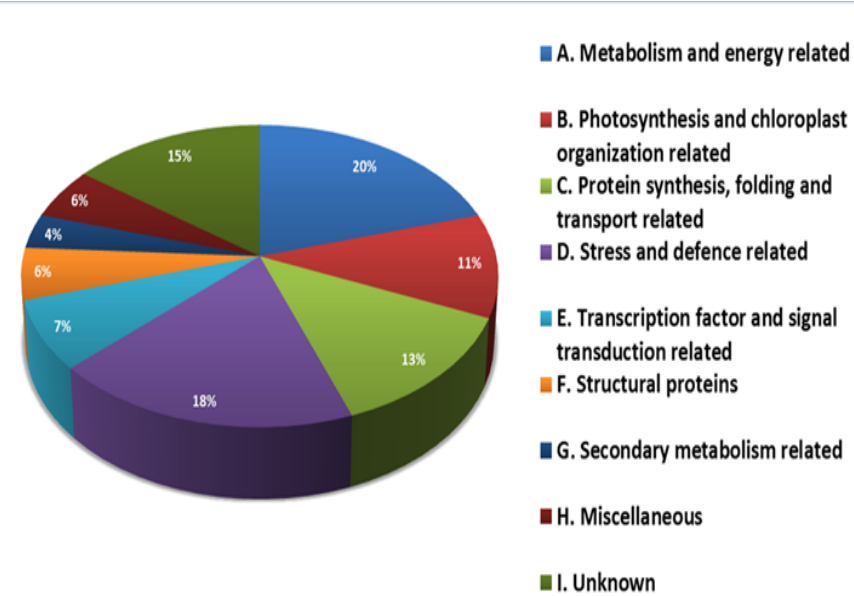

Supplementary Figure 4 Functional categories of the differentially abundant proteins as predicted by using Blast2Go software (v. 3.0) and UniProt database.

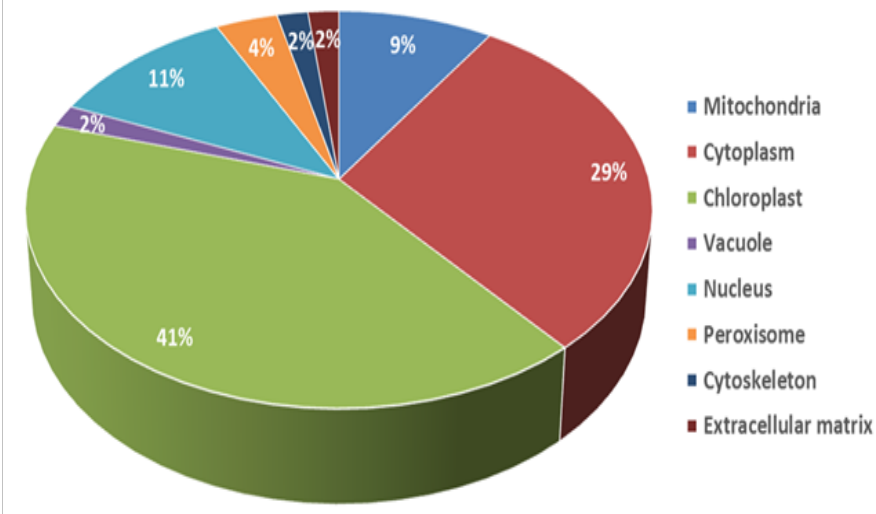

Supplementary Figure 5 Subcellular localisation of identified proteins as predicted by using WoLF PSORT online software. The findings were compared with the subcellular localisation information documented in different protein databases.

The functional categories included metabolism and energy related (group A, $\mathrm{n}=11$ ), photosynthesis and chloroplast organization related (group $\mathrm{B}, \mathrm{n}=6$ ), protein synthesis, folding and transport related (group $\mathrm{C}, \mathrm{n}=7$ ), stress and defence related (group $\mathrm{D}, \mathrm{n}=10$ ), transcription factor and signal transduction related (group $\mathrm{E}, \mathrm{n}=4$ ), structural proteins (group $\mathrm{F}, \mathrm{n}=3$ ), secondary metabolism related (group $\mathrm{G}$, $\mathrm{n}=2$ ) and proteins of miscellaneous function (group $\mathrm{H}, \mathrm{n}=3$ ). About $15 \%$ of the differentially abundant proteins could not be identified and hence categorized as unknown (group $\mathrm{I}, \mathrm{n}=8$ ). The largest groups of the identified proteins were related to metabolism (group A, 20\%) along with stress and defence related proteins (group D, 18\%). The maximum number $(37 \%)$ of differentially abundant proteins were found to be localized in chloroplast, followed by cytoplasm (29\%), nucleus (15\%) and mitochondria (9\%) (Supplementary Figure 5). The functional categories as predicted by using Blast2Go software were similar to KEGG and UniProt databases. On the other hand, the subcellular localization as predicted by WoLF PSORT software had difference with UniProt database only in three cases (spot no. 10, 34 and 39). However, the subcellular localizations documented by UniProt database were finally considered. A heat map profile was generated to compare the differentially abundant protein among the plant lines of B. monnieri (Figure 2).

\section{Relative expression of key enzymes of representative secondary metabolite biosynthetic pathway and $\mathrm{pr} I$ in B. monnieri plant lines}

To further validate the 2D-GE results, out of 54 spots the relative expression of 13 genes involved in secondary metabolism and defence responses in B. monnieri plant lines harboring crypt gene (BmAtncrypt) was compared with that of non-transformed (Bm-NT) as well as empty vector control (BmAt-n) plant lines by qRT-PCR analysis (Figure 3).

High to moderately variable expression pattern was observed for the MVA pathway enzymes. The expression of hmgr and fpps were downregulated $(\mathrm{p} \leq 0.05)$ by 2.1 -fold and 1.4 -fold respectively in BmAt-ncrypt plant lines with respect to Bm-NT. On the other hand, the expression of $m v k$ and $m d c$ was upregulated $(\mathrm{p} \leq 0.05)$ by 62.5-fold and 6.6-fold respectively in BmAt-ncrypt compared to Bm-NT. The expression of three key genes encoding the enzymes of triterpenoid saponin biosynthetic pathway viz., sqs, bas and ugt 2 were found to be significantly upregulated $(\mathrm{p} \leq 0.05)$ by $1.6,1.8$ and 7.0-fold respectively in crypt-transgenic plant lines BmAt-ncrypt than that of Bm-NT. However, dxs, encoding an enzyme of MEP pathway was downregulated $(\mathrm{p} \leq 0.05)$ in BmAt-ncrypt with respect to Bm-NT by 2.2 -fold. However, the expression pattern of dahs (belonging to shikimic acid pathway) and $f g t$ (involved in flavonoid biosynthesis) was similar between Bm-NT and BmAt-ncrypt plant lines. Strikingly, 
the expression of all the genes involved in triterpenoid saponin biosynthesis was significantly downregulated $(p \leq 0.05)$ in BmAt-n in

comparison with BmAt-ncrypt plant lines.

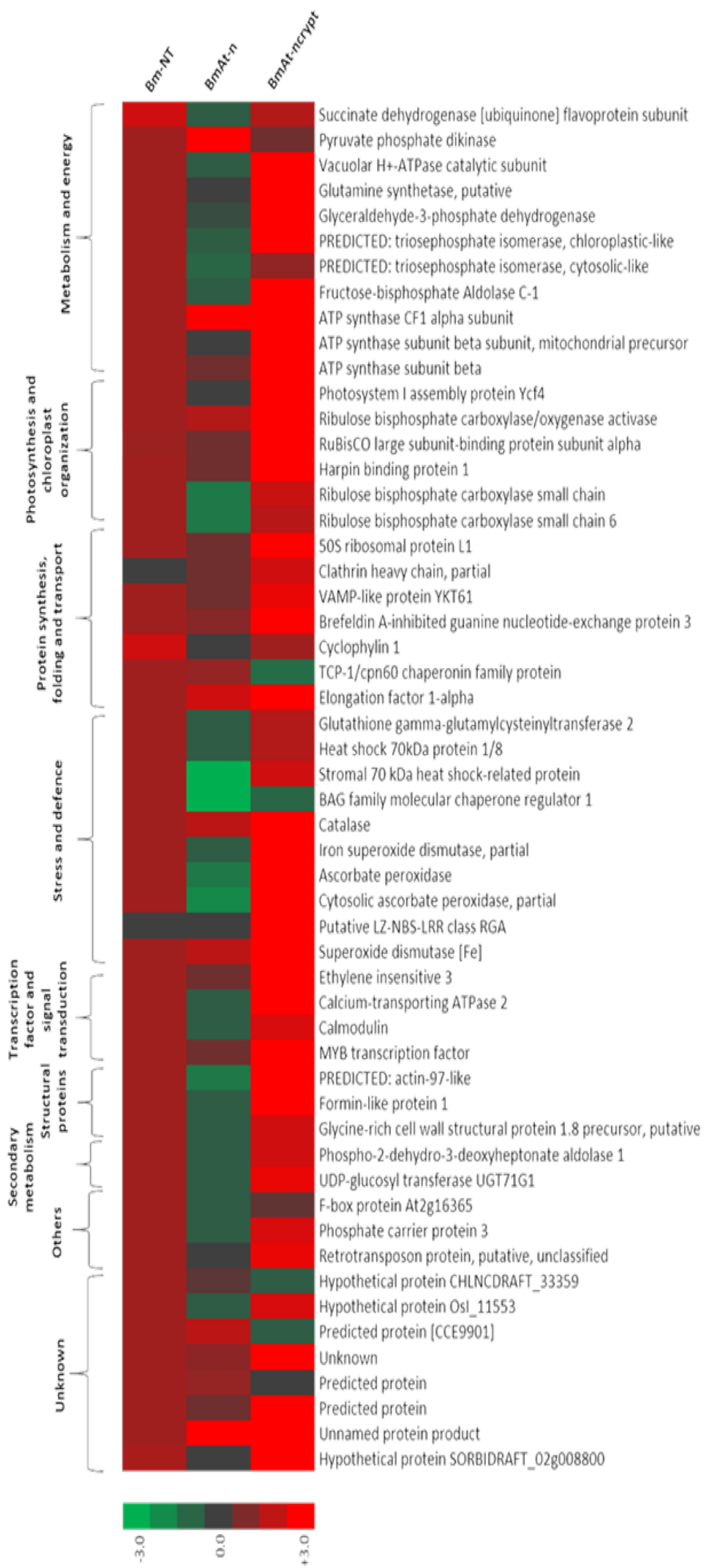

Figure 2 Heat map profile of differentially abundant proteins between Bm-NT, BmAt-n and BmAt-ncrypt plant lines. 
The expression of a defence marker gene $\operatorname{pr} 1$ was also included in the responses through PR proteins. However, relative expression of $p r 1$ present study to demonstrate whether over expression of crypt in crypt- was found to be similar among different plant lines (Figure 3 ). transgenic plant lines of $B$. monnieri results in induction of defence

aact

hmgr

mvk
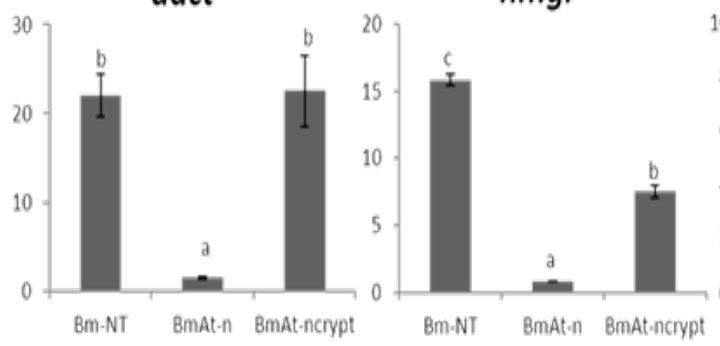

fpps

mdc
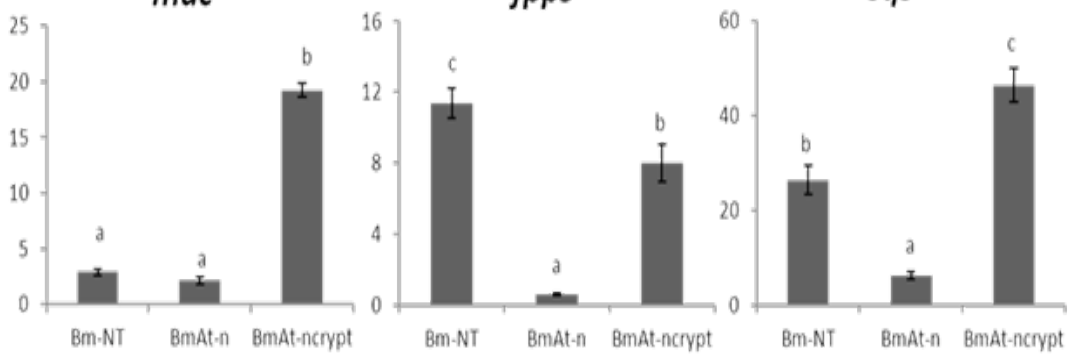

bas

ugt 1

ugt 2
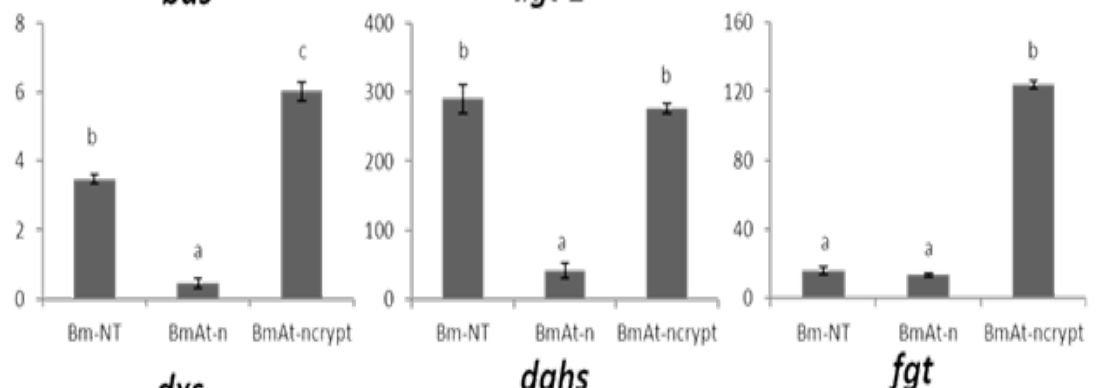

$d x s$

dahs
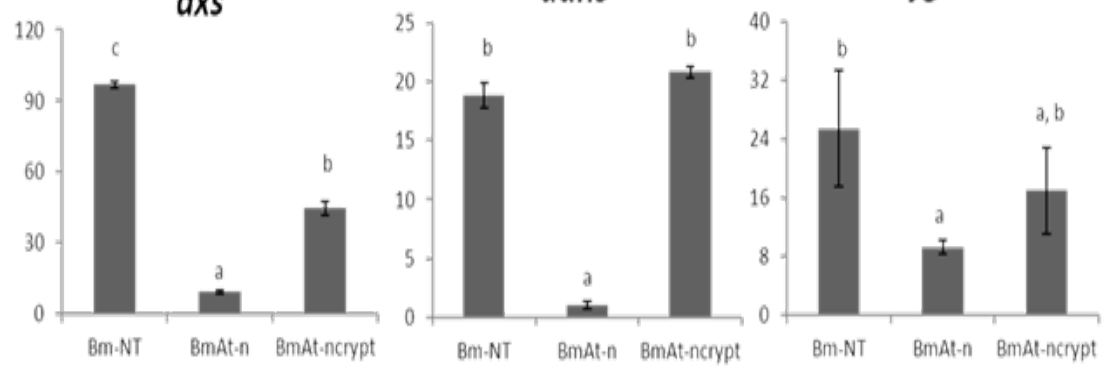

pr 1

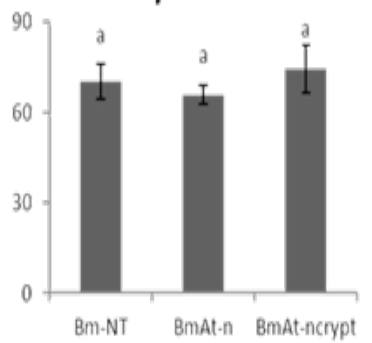

Figure 3 Relative expression analysis of 13 genes related to secondary metabolism and defence response among the non-transformed (Bm-NT), empty vector control (BmAt-n) and crypt-transgenic (BmAt-ncrypt) plant lines by qRT-PCR. In the Y-axis relative gene expression was plotted.Values represent mean \pm standard error (SEM) of three independent experiments $(n=9)$. Bars with the same letter are not significantly different according to ANOVA and Tuky's multiple comparison test $(p \leq 0.05)$ as calculated using SPSS (v. 20.0) software. 
Effect of crypt on reactive oxygen species (ROS) scavenging enzymes in leaves of crypt-transgenic plants of B. monnieri

Antioxidant enzyme activity assay was performed in order to validate the findings of higher abundance of a number of ROS scavenging enzymes in the leaf proteome of crypt-transgenic plants (BmAt-ncrypt) of B. monnieri than that of the non-transformed (Bm-
NT) and empty vector control (BmAt-n) plants.

The activity of CAT, APX and SOD were recorded significantly higher $(\mathrm{p} \leq 0.05)$ in BmAt-ncrypt compared to Bm-NT $(2.57$-fold, 2.47-fold and 2.21-fold higher respectively). Interestingly, activities of APX and SOD were similar between Bm-NT and BmAt-n plant lines, whereas activities of CAT and GPX were significantly higher $(\mathrm{p} \leq 0.05)$ in Bm-NT than that of BmAt-n plant lines (Figure 4).
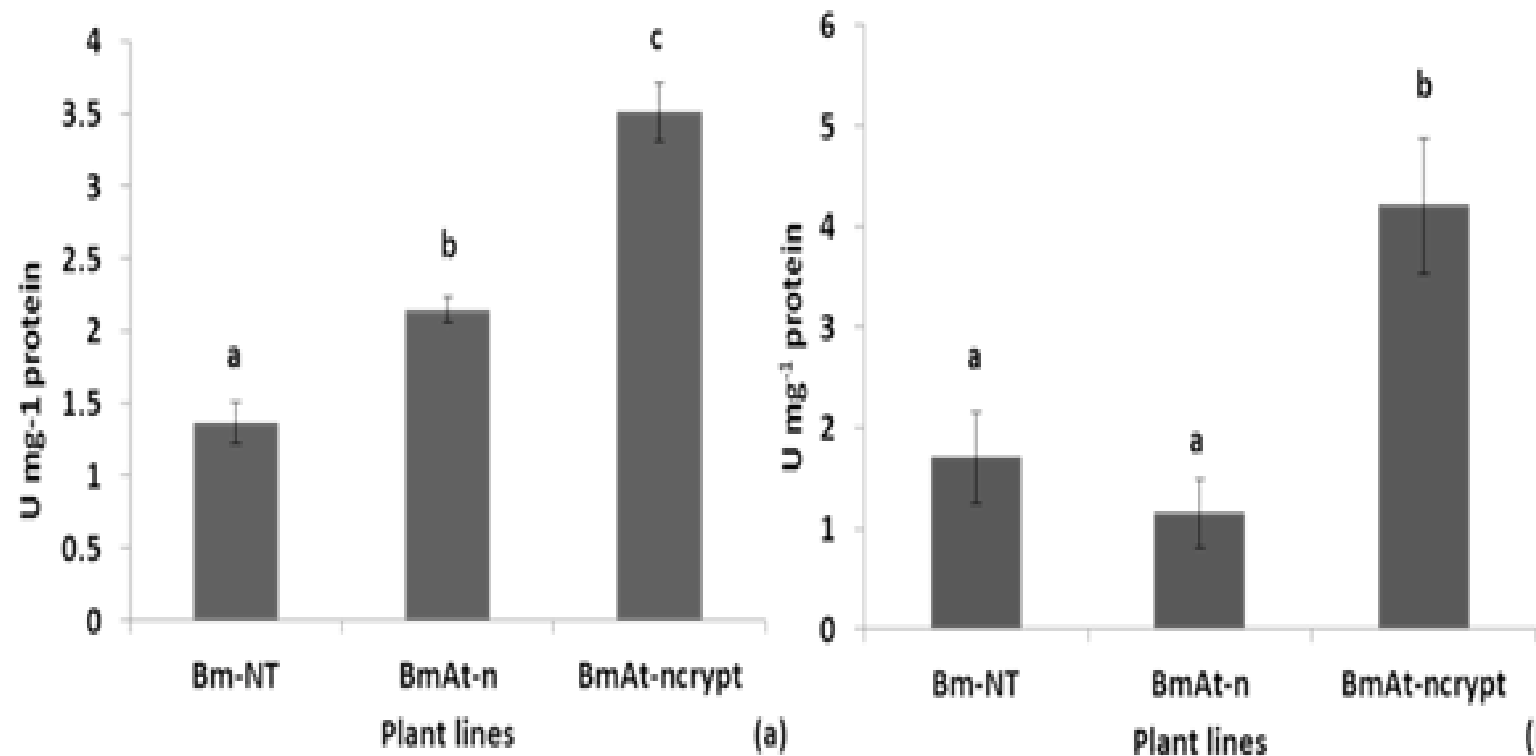

(a)

Plant lines

(b)

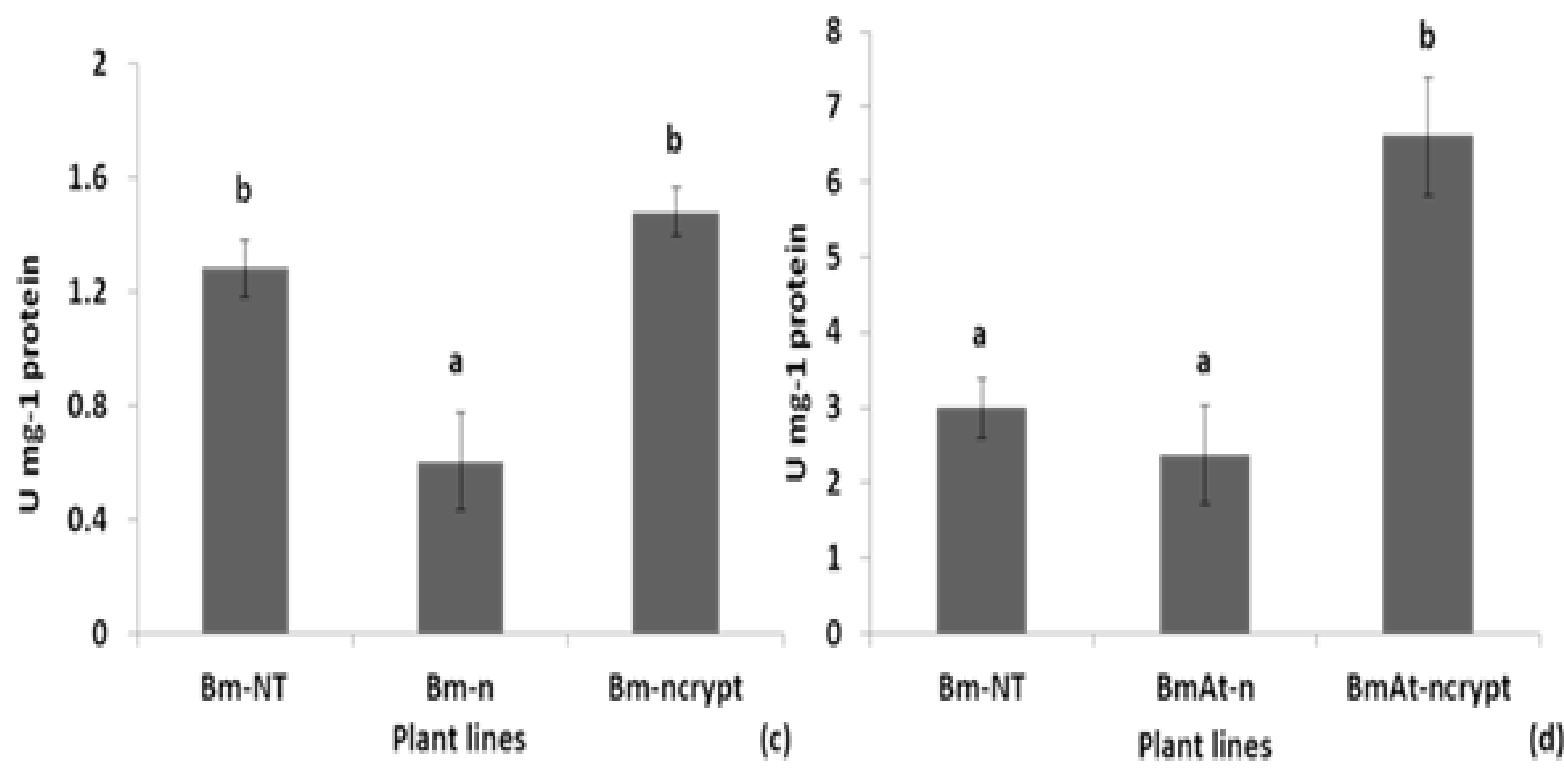

Figure 4 Specific activity of anti-oxidant enzymes in different plant lines of B. monnieri.
A. CAT activity ( $\mathrm{U} \mathrm{mg}-\mathrm{I}$ protein)
B. APX activity (U mg-I protein)
C. GPX activity (U mg-I protein) and
D. SOD activity ( $\mathrm{U} \mathrm{mg}-\mathrm{I}$ protein)

Bars with the same letter are not significantly different according to ANOVA and Tukey's multiple comparison test ( $\mathrm{p} \leq 0.05)$ as calculated using SPSS ( $v$. 20.0) software. 


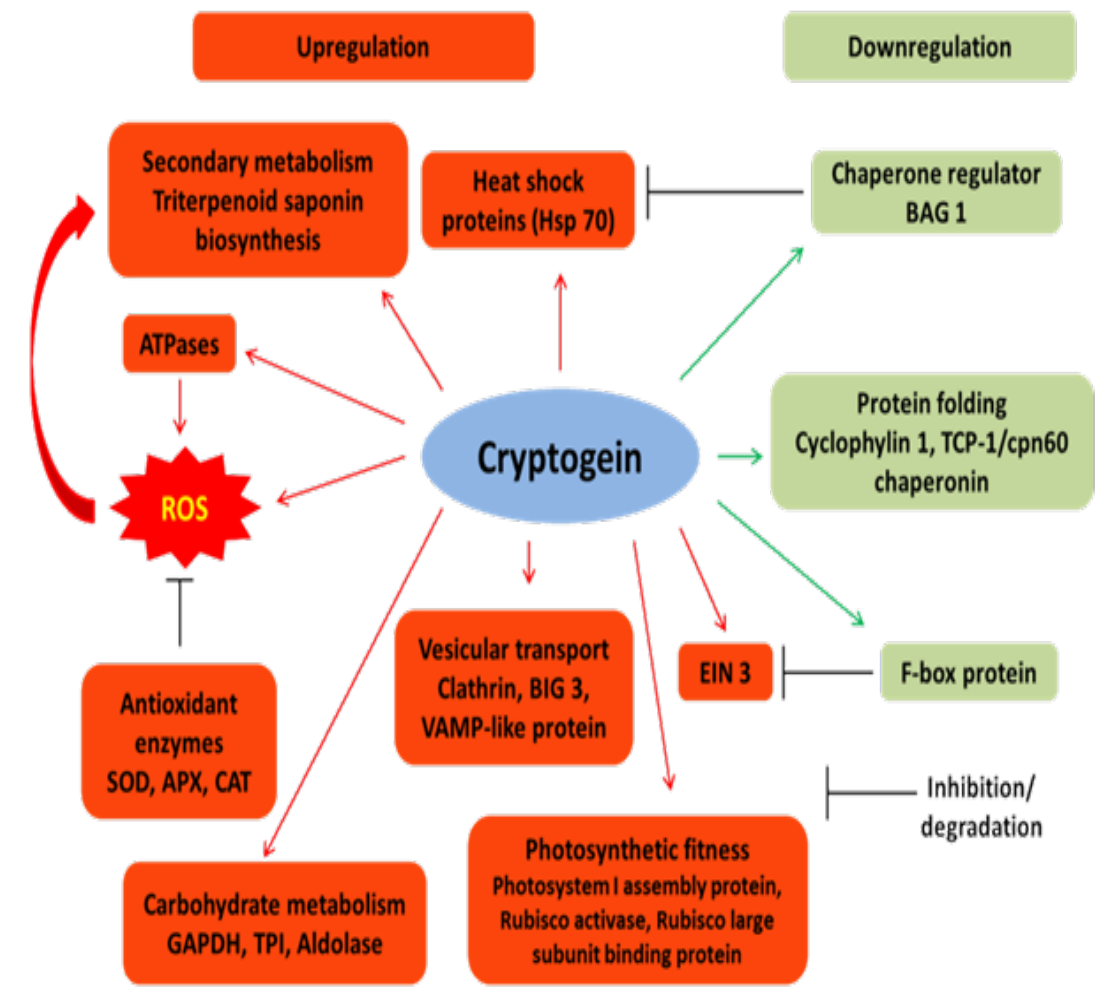

Figure 5 Alteration in abundance of proteins and biochemical changes associated with endogenous expression of cryptogein gene in crypt-transgenic plants of B. monnieri. Red arrow and green arrow indicate upregulation and downregulation respectively.

\section{Discussion}

Cryptogein (crypt)-induced elicitation, as established in transgenic plants expressing crypt gene showed enhanced accumulation of secondary metabolites in many plant species, ${ }^{7,9,30}$ including $B$. monnieri ${ }^{19,20}$ In the present study, we compared the whole leaf proteome using 2DGE to understand the cross-talks between different plant defence systems that ultimately promoted bacosides (triterpenoid saponins) biosynthesis in crypt-transgenic plant lines as evident in our previous study. ${ }^{20}$ Using a broad $\mathrm{pH}$ range IPG strip (pH 3-11) 54 differentially abundant proteins were identified and function of $85 \%$ of these differentially abundant proteins could be identified in the present study. The relative expression of genes and their relevance was further examined for 13 out of 54 differentially abundant proteins.

The relative gene expression of key enzymes of triterpenoid saponin biosynthetic pathway viz., $m v k, m d c, s q s$, bas and ugt2 was found to be enhanced in crypt-transgenic plant lines of B. monnieri (BmAtncrypt) (Figure 3). Importantly, a 62.5-fold higher expression of $m v k$ and 6.6-fold higher expression of $m d c$ in BmAt-ncrypt relative to BmNT (non-transformed plants) was observed, implicating stimulation of MVA pathway in BmAt-ncrypt plant lines and possibly helping in overcoming marginal downregulation of $h m g r$ and fpps. Triterpenoids and sesquiterpenoids are synthesized via the MVA pathway, whereas monoterpenoids, diterpenoid, and tetraterpenoids are synthesized via the MEP pathway. ${ }^{31}$ The downregulation of $d x s$ of MEP pathway and at the same time upregulation of $m v k$ and $m d c$ of MVA pathway suggest the inclination towards triterpenoids biosynthesis in crypttransgenic plants. Significant upregulation $(\mathrm{p} \leq 0.05)$ of genes encoding branch point enzymes of tri-terpene biosynthesis (viz., sqs, bas and ugt 2) contributes positively towards higher bacosides accumulation in crypt-transgenic plant lines as reported in our earlier work. ${ }^{20}$ In Withania somnifera crypt-co-transformed hairy roots, a metabolic shift from withasteroid (an end product of MVA pathway) formation to phenyl propanoid accumulation was observed. ${ }^{32}$ However, in our study, endogenous expression of crypt rather stimulated several genes of MVA and downstream triterpenoid saponin biosynthetic pathway, thus inducing higher bacosides accumulation in crypt-transgenic plant lines over non-transformed plants. So, it can be predicted that cryptogein-induced elicitation is probably species specific and may not elicit major end products of respective secondary metabolite biosynthetic pathways in the particular plant under study.

ROS are formed in many cellular reactions, including those involving cytochrome $\mathrm{P} 450$, peroxidase, lipoxygenase, and NADPH oxidase. ROS produced during the oxidative burst after the pathogen attack was implicated to induce defence responses. ${ }^{33}$ The ROS scavenging enzymes include SOD, the first line of defence catalyzing the dismutation of superoxide anions $\left(\mathrm{O}_{2}^{-}\right)$to $\mathrm{H}_{2} \mathrm{O}_{2}$; APX, GPX and CAT, which are responsible for further detoxification of $\mathrm{H}_{2} \mathrm{O}_{2}$. Significantly higher abundance (2.0-2.5-fold) of a number of ATPases localized in vacuole, mitochondria and chloroplast (Figure 2) may contribute in elevated reactive oxygen species (ROS) production in crypt-transgenic plant lines over non-transformed plants. In cryptogein-induced HR the major enzymes responsible for a rapid generation of a huge amount of ROS are NADPH oxidases. ${ }^{15}$ Strikingly, upregulation of none of the NADPH oxidases could be detected in this study. However, elicitor induced ROS production, a typical response of the plant cells towards cryptogein could indirectly be confirmed by significantly higher $(\mathrm{p} \leq 0.05)$ specific activity (Figure 4 ) as well as higher abundance of several ROS scavenging enzymes, such as SOD (3.0-5.0-fold), APX (2.3-3.0-fold) and CAT (2.6-fold) in crypt-transgenic plants over non-transformed and empty vector control plants of B. monnieri. Kumar et al..$^{30}$ reported similar findings where significantly higher activity of antioxidant enzymes along with 
lower abundance of ROS was observed in tobacco plantlets expressing $\beta$-cryptogein. ${ }^{30}$

Interestingly, two proteins associated with protein folding in stress-free condition viz., cyclophylin 1 and TCP-1/cpn60 chaperonin family protein were downregulated in both BmAt-n and BmAt-ncrypt plant lines. In addition, two isoforms of heat shock proteins (HSPs) were expressed in higher abundance and BAG family molecular chaperone regulator 1 (BAG 1) was downregulated in BmAt-ncrypt in comparison with Bm-NT plant line. Down regulation of BAG 1, an inhibitor of $\mathrm{HSPs}^{34}$ might be responsible for the higher abundance of HSP 70 family in crypt-transgenic plants. However, the Hsp 70 family proteins often act as molecular chaperons during various physico-chemical stresses, including oxidative stress. ${ }^{35}$ Upregulation of glutathione gamma-glutamyl cysteinyl transferase 2 (PCS 2), aphytochelatin synthase involved in heavy metal detoxification ${ }^{36}$ further signifies cryptogein-induced stress in BmAt-ncrypt plant lines. Undoubtedly, the crypt-transgenic plants survived the constitutive expression of cryptogein, most likely by the activity of ROS scavenging enzymes, HSPs, PCS among others that could relentlessly be preventing from cellular damage.

In addition, similar expression pattern of $p r 1$ among the plant lines (Figure 3) indicates that cryptogein may not induce defence responses through PR proteins-mediated defence pathway in crypt-transgenic plants of $B$. monnieri. This observation is in agreement with the findings of Amelot et al., ${ }^{2}$ where treatment of tobacco BY-2 cells with purified cryptogein protein failed to induce significant upregulation $(\mathrm{p} \leq 0.05)$ of $p r 1,2$ and 3 genes.

Understanding signal transduction pathways underlying cryptogein-induced production of secondary metabolites is very important in elucidating the highly complex events that occur during elicitation. The elicitor signal transduction involves several signal molecules and multiple defence pathways. ${ }^{37,38}$ Cryptogein-mediated elicitation in $B$. monnieri is likely calcium-dependant as suggested by the higher abundance of calmodulin (CaM) (1.6-fold) along with calcium-transporting ATPase 2 (2.0-fold) in crypt-transgenic plants over non-transformed plants. In fact, $\mathrm{Ca}^{2+} / \mathrm{CaM}$ complex has been implicated in a variety of physiological processes including phytohormone signalling, transcriptional regulation, protein phosphorylation and dephosphorylation. ${ }^{39}$

A three-fold higher abundance of EIN3 in crypt-transgenic plants (BmAt-ncrypt) over non-transformed plants (Bm-NT) suggested that cryptogein-induced elicitation in crypt-transgenic plants of $B$. monnieri might be mediated through JA-ET signalling pathway. Another interesting observation was the downregulation (-0.65-fold) of an $\mathrm{F}$ box protein in BmAt-ncrypt. However, EBF1 and EBF2, the two $\mathrm{F}$ box proteins regulate the EIN3 protein levels through a ubiquitin/proteosome pathway. ${ }^{40}$ Therefore, downregulation of $\mathrm{F}$ box protein might provide the enhanced stability to EIN3. From these observations it can be assumed that in many aspects the defence responses elicited by endogenous expression of crypt gene were very similar to the exogenous treatment of purified cryptogein protein, regarding the induction of defence signalling pathways. An evidence of the involvement of JA-ET-mediated signalling in cryptogeininduced elicitation of $B$. monnieri crypt-transgenic plants is a novel finding of the present study.

Higher abundance of three vesicle-associated proteins, such as clathrin (1.5-fold), VAMP-like protein (1.8-fold) and Brefeldin A-inhibited guanine nucleotide-exchange protein 3 (BIG 3) (2.1-fold) was observed in crypt-transgenic plants suggesting involvement of secretory pathway of protein trafficking in crypt-transgenic plant line. Important to note that rate of vesicular transport or secretion have not been measured in this study. Interestingly, Leborgne-Castel et al. ${ }^{41}$ reported ROS dependant increase of clathrin-mediated endocytosis after addition of cryptogein to tobacco Bright Yellow-2 (BY-2) cells followed by the elicitation of defence responses.

Unexpectedly robust effect on primary metabolism was also observed in crypt-transgenic plants over non-transformed plants, signified by the upregulation of two key glycolytic enzymes, viz., GAPDH (2.3-fold) and TPI (2.1-fold). Interestingly, carbohydrate metabolism was found to be altered in cryptogein-treated tobacco cells $\mathrm{Ca}^{2+}$-dependant NADPH oxidation caused by cryptogein activates the cytosolic pentose phosphate pathway and eventually provides the glycolytic intermediates thus, triggering glycolysis. ${ }^{42}$ A recent study showed that over expression of aldolase, an enzyme of Calvin cycle enhanced growth and promoted photosynthetic $\mathrm{CO}_{2}$ fixation in the transgenic tobacco plants. ${ }^{4} 3$ Therefore, higher expression of plastidial aldolase (5.8-fold) along with GAPDH and TPI in crypt-transgenic plants over non-transformed plants was likely a contributing factor behind the higher growth rate of crypt-transgenic plant lines as reported in our previous study. ${ }^{20}$

In the present study a broad $\mathrm{pH}$ range IPG strip ( $\mathrm{pH}$ 3-11) has been used, a narrower $\mathrm{pH}$ range (e.g., $\mathrm{pH}$ 4-7) for IEF may be used for better resolution and the issue of protein masking, if any, could be addressed. Several proteins (spot no. 2, 16, 20, 22, 30, 32, 36 and 40; tryptic fingerprint data were tabulated in Supplementary Table 3) could not be identified even with sufficient MS and/or MS/MS signals, probably due to the unavailability of sequence data of those specific proteins in the public databases considered in MASCOT search engine. These unknown, novel proteins need to be identified and further characterized in order to understand their functional relevance in present context.

In the present study, a cross-talk between ROS scavenging system, plant defence and secondary metabolite biosynthetic pathways in cryptogein-induced elicitation is suggested in crypt-transgenic plants of B. monnieri (Figure 5). Higher abundance of a number of defence and stress related proteins in crypt-transgenic plants prove the hypothesis that endogenous expression of crypt mimics the pathogen attack caused by the exogenous treatment of cryptogein protein. However, higher accumulation of bacosides might be the consequences of cryptogein-induced defence responses leading to the stimulation of expression of genes encoding key enzymes of triterpenoid saponin biosynthetic pathway.

\section{Acknowledgements}

Pijush Paul gratefully acknowledges the University Grant Commission (UGC), Govt. of India for award of Senior Research Fellowship in the Department of Genetics, University of Calcutta. The authors thank Head, Department of Genetics; Head, Department of Botany, University of Calcutta and coordinator, DBT-IPLS-CU for the facilities provided.

\section{Conflict of interest}

All the authors declare that they have no conflict of interest. 


\section{References}

1. Ricci P, Bonnet P, Huet JC, et al. Structure and activity of proteins from pathogenic fungi Phytuphthura eliciting necrosis and acquired resistance in tobacco. Eur J Biochem. 1989;183(3):555-563.

2. Ponchet M, Panabières F, Milat ML, et al. Are elicitins cryptograms in plant-Oomycete communications? Cell Mol Life Sci. 1999;56(1112):1020-1047.

3. Devergne JC, Bonnet P, Panabières F, et al. Migration of the fungal protein cryptogein within tobacco plants. Plant Physiol. 1992;99(3):843847.

4. Keller H, Blein JP, Bonnet P, et al. Physiological and molecular characteristics of elicitin-induced systemic acquired resistance in tobacco. Plant Physiol. 1996;110(2):365-376.

5. Tepfer D, Boutteaux C, Vigon C, et al. Phytophthora resistance through production of a fungal protein elicitor ( $\beta$-Cryptogein) in Tobacco. APS. 1998;11(1):64-67.

6. Donghua J, Zejian G, Xujun C, et al. Study on tobacco disease resistances mediated by the elicitor gene cryptogein from Phytophthora cryptogea. Chinese Journal of Agricultural Biotechnology. 2004;1(2):125-131.

7. Chaudhuri K, Das S, Bandyopadhyay M, et al. Transgenic mimicry of pathogen attack stimulates growth and secondary metabolite accumulation. Transgenic Res. 2009;18(1):121-134.

8. Vuković R, Bauer N, Perica MC. Genetic elicitation by inducible expression of $\beta$-cryptogein stimulates secretion of phenolics from Coleus blumei hairy roots. Plant Sci. 2013;199-200:18-28.

9. Basu A, Roychowdhury D, Raj Kumar Joshi, et al. Effects of cryptogein gene on growth, phenotype and secondary metabolite accumulation in co-transformed roots and plants of Tylophora indica. Acta Physiologiae Plantarum. 2017;39:3.

10. Wendehenne D, Noëlle Binet M, Pierre Blein J, et al. Evidence for specific, high-affinity binding sites for a proteinaceous elicitor in tobacco plasma membrane. FEBS Letters. 1995;374(2):203-207.

11. Buhot N, Douliez JP, Jacquemard A, et al. A lipid transfer protein binds to a receptor involved in the control of plant defence responses. FEBS Lett. 2001;509(1):27-30.

12. Lebrun-Garcia A, Ouaked F, Chiltz A, et al. Activation of MAPK homologues by elicitors in tobacco cells. Plant J. 1998;15(6):773-781.

13. Dahan J, Pichereaux C, Rossignol M, et al. Activation of a nuclear-localized SIPK in tobacco cells challenged by cryptogein, an elicitor of plant defence reactions. Biochem J. 2009;418(1):191-200.

14. Amelot N, De Borne FD, San Clemente H, et al. Transcriptome analysis of tobacco BY-2 cells elicited by cryptogein reveals new potential actors of calcium-dependent and calcium-independent plant defense pathways. Cell Calcium. 2012;51(2):117-130.

15. Simon-Plas F, Elmayan T, Blein JP. The plasma membrane oxidase NtrbohD is responsible for AOS production in elicited tobacco cells. Plant J. 2002;31(2):137-147.

16. Amelot N, Carrouche A, Danoun S, et al. Cryptogein, a fungal elicitor, remodels the phenylpropanoid metabolism of tobacco cell suspension cultures in a calcium-dependent manner. Plant Cell Environ. 2011;34(1):149-161.

17. Dokládal L, Obořil M, Stejskal K, et al. Physiological and proteomic approaches to evaluate the role of sterol binding in elicitin-induced resistance. Journal of Experimental Botany. 2012;63(5):2203-2215.

18. Majumdar S, Basu A, Paul P, et al. Bacosides and neuroprotection. In: Ramawat KG, et al. editors. Handbook of natural products-phytochemistry. Berlin, Germany: Springer; 2013. p. 3639-3660.
19. Majumdar S, Garai S, Jha S. Use of the cryptogein gene to stimulate the accumulation of bacopa saponins in transgenic Bacopa monnieri plants. Plant Cell Rep. 2012;31(10):1899-1909.

20. Pijush P, Sayantika S, Sumita J. Effects associated with insertion of cryptogein gene utilizing Ri and Ti plasmids on morphology and secondary metabolites are stable in Bacopa monnieri-transformed plants grown in vitro and ex vitro. Plant Biotechnology Reports. 2015;9(4):231-245.

21. O’Donohue MJ, Gousseau H, Huet JC, et al. Chemical synthesis, expression and mutagenesis of a gene encoding $\beta$-cryptogein, an elicitin produced by Phytophthoracryptogea. Plant Mol Biol. 1995;27(3):577-586.

22. Wang W, Vignani R, Scali M, et al. A universal and rapid protocol for protein extraction from recalcitrant plant tissues for proteomic analysis. Electrophoresis. 2006;27(13):2782-2786.

23. Bradford MM. A rapid and sensitive method for the quantitation of microgram quantities of protein utilizing the principle of protein-dye binding. Anal Biochem. 1976;72:248-254.

24. Shevchenko A, Tomas H, Havlis J, et al. In-gel digestion for mass spectrometric characterization of proteins and proteomes. Nat Protoc. 2006;1(6):2856-2860.

25. Gohain B, Borchetia S, Bhorali P, et al. Understanding Darjeeling tea flavour on a molecular basis. Plant Mol Biol. 2012;78(6):577-597.

26. Bergmeyer HU. Methoden der enzymatischen Analyse. 2nd ed. Germany: Verlag Chemie; 1970.

27. Nakano Y, Asada K. Hydrogen-peroxide is scavenged by ascorbate-specific peroxidase in spinach-chloroplasts. Plant and Cell Physiology. 1981;22(5):867-880.

28. Chance B, Maehly AC. Assay of catalases and peroxidases. Methods in Enzymology. 1955;2:773-775.

29. Beauchamp C, Fridovich I. Superoxide dismutase: Improved assays and an assay applicable to acrylamide gels. Anal Biochem. 1971;44(1):276287

30. Kumar M, Basu A, Kumari P, et al. Tobacco plantlets ameliorate oxidative stress upon expression of a cryptogein gene. Plant Cell, Tissue and Organ Culture. 2016;125(3):553-570.

31. Sawai S, Saito K. Triterpenoid biosynthesis and engineering in plants. Front Plant Sci. 2011;2:25.

32. Sil B, Mukherjee C, Jha S, et al. Metabolic shift from withasteroid formation to phenylpropanoid accumulation in cryptogein-cotransformed hairy roots of Withania somnifera (L.) Dunal. Protoplasma. 2015;252(4):1097-1110.

33. Torres MA. ROS in biotic interactions. Physiol Plant. 2010;138(4):414 429 .

34. Kabbage M, Dickman MB. The BAG proteins: A ubiquitous family of chaperone regulators. Cell Mol Life Sci. 2008;65(9):1390-1402.

35. Wang W, Vinocur B, Shoseyov O, et al. Role of plant heat-shock proteins and molecular chaperones in the abiotic stress response. Trends Plant Sci. 2004;9(5):244-252.

36. Zenk MH. Heavy metal detoxification in higher plants-A review. Gene. 1996;179(1):21-30.

37. Zhao J, Davis LC, Verpoorte R. Elicitor signal transduction leading to production of plant secondary metabolites. Biotechnol Adv. 2005;23(4):283-333.

38. Garcia-Brugger A, Lamotte O, Vandelle E, et al. Early signaling events induced by elicitors of plant defenses. Mol Plant Microbe Interact. 2006;19(7):711-724. 
39. Kim MC, Chung WS, Yun DJ, et al. Calcium and calmodulin-mediated regulation of gene expression in plants. Mol Plant. 2009;2(1):13-21.

40. Kendrick MD, Chang C. Ethylene signaling: new levels of complexity and regulation. Curr Opin Plant Biol. 2008;11(5):479-485.

41. Leborgne-Castel N, Lherminier J, Der C, et al. The plant defense elicitor cryptogein stimulates clathrin-mediated endocytosis correlated with reactive oxygen species production in bright yellow-2 tobacco cells. Plant Physiol. 2008;146(3):1255-1266.
42. Pugin A, Frachisse JM, Tavernier E, et al. Early events induced by the elicitor cryptogein in tobacco cells: involvement of a plasma membrane NADPH oxidase and activation of glycolysis and the pentose phosphate pathway. Plant Cell. 1997;9(11):2077-2091.

43. Uematsu K, Suzuki N, Iwamae T, et al. Increased fructose 1,6-bisphosphate aldolase in plastids enhances growth and photosynthesis of tobacco plants. J Exp Bot. 2012;63(8):3001-3009. 